\title{
Driven from the Tribunal: Judicial Resolution of Internal Church Disputes
}

\author{
Ira Mark Ellman
}

TABLE OF CONTENTS

PAGE

INTRODUCTION $\ldots \ldots \ldots \ldots \ldots \ldots \ldots \ldots \ldots \ldots \ldots \ldots \ldots \ldots \ldots \ldots \ldots$

I. Development of the Traditional Doctrine........ 1385

A. Watson v. Jones.......................... 1385

1. Congregational Churches: Ordinary Voluntary Associations .......................... 1386

2. Hierarchical Churches: Three Deference

Principles ........................... 1387

a. The Contract Principle ................. 1387

b. The Ban on Doctrinal Decisions........... 1388

c. Strict Deference ..................... 1388

B. Developments After Watson.................. 1389

II. EnForcing Church Rules .................... 1400

A. Why Courts Ought to Employ the Contract Principle

and Enforce Church Rules .................... 1401

1. Consistency with Our Sense of Justice .......... 1402

2. Protecting the Religious Freedom of Church

Members ............................. 1403

3. Enforcement as an Organizational Aid ........... 1404

4. The Absence of Satisfactory Alternatives .......... 1405

a. Strict Deference ...................... 1405

i. The failure to explain the different treatment of hierarchical churches................. 1405

ii. The difficulty in identifying which churches are hierarchical ....................... 1406

b. Neutral Principles...................... 1407

$i$. The formal title doctrine .............. 1408

ii. Deference to the hierarchy's definition of religious terms ........................ 1409

iii. Determination of which faction speaks for the congregation ................... 1409

B. Remaining Problems with the Contract Principle ....... 1410 
1. Two False Problems ......................... 1410

a. The "Hands-Off" Argument ................ 1410

b. The "Dismal Swamp" Rationale ............. 1412

2. Two Real Problems ......................... 1413

a. Doctrinal Decisions ..................... 1413

b. Vagueness: Is There an Enforceable

Agreement? ........................... 1417

C. Conclusion ................................ 1420

III. Applying External Rules...................... 1421

A. Procedural Fairness ............................. 1422

B. Fiduciary Obligations ........................ 1428

1. The Traditional Trust Rules ................. 1428

2. The Use of Trust Principles to Vindicate Donors'

Contractual Interests ....................... 1430

3. The Use of Trust Principles to Impose External

Policies .................................. 1437

a. Overriding Donor Consent ............... 1437

b. The Problem of Fashioning Presumptions ...... 1439

C. Conclusion ................................... 1443

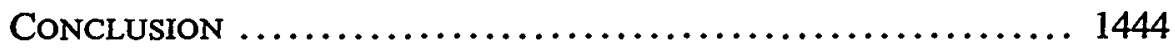




\title{
Driven from the Tribunal: Judicial Resolution of Internal Church Disputes*
}

\author{
Ira Mark Ellman†
}

Any organization may experience internal dissension. If the dispute contmues, one faction may seek a judicial resolution. For business corporations, social clubs, charities, or trade associations, such aid is normally available. ${ }^{1}$ But if the organization is a church, concern over the propriety of state intervention may cause a court to refrain from deciding the dispute. This concern has a long history. ${ }^{2}$ In the United States, the religion clauses of the first amendment transform it into a constitutional question. ${ }^{3}$

The practical importance of this constitutional question is illustrated by the surprismg number of hitigated church disputes. They often involve significant sums of money, as where two factions battle for control over church property. ${ }^{4}$ There are also battles within local

* But when Gallio was proconsul of Achaia, the Jews made a united attack upon Paul and brought him before the tribunal, saymg, "This man is persuading men to worship God contrary to the law." But when Paul was about to open his mouth, Gallio said to the Jews, "lf it were a matter of wrongdoing or vicious crime, I should have reason to bear with you, $O$ Jews; but since it is a matter of questious about words and names and your own law, see to it yourselves; I refuse to be a judge of these things." And he drove thein from the tribunal.

Acts 18:14-16 (Rev. Standard Version).

$\dagger$ Professor of Law, Arizona State University College of Law. B.A. 1967, Reed College; M.A. 1969, Umiversity of Illinois; J.D. 1973, Univcrsity of California, Berkeley. Much of the research for this Article was done with the support of a university researcl grant from Arizona State Umiversity. Part III of this Article was completed with the support of the Program on NonProfit Organizations, at the Institution for Social and Policy Studies, Yale University. The author is grateful for the comments received from a number of colleagues who had the patience to read portions of earlier drafts. Special thanks are due Gary Lowenthal, whose careful reading of the first draft inspired substantial revisions. The author is also grateful for the assistance of Lewis Gruber.

1. See Developments in the Law-Judicial Control of Actions of Private Associations, 76 HARV. L. REV. 983 (1963).

2. See O'Brien \& O'Brien, Separation of Church and State in Restatement of Inter-Clurchand-State Common Law, 7 JuRist 259, 267-68 (1947).

3. "Congress shall make no law respecting an establishment of religion, or prohibiting the free exercise thereof. . . ." U.S. CoNST. amend. I.

4. All but one of the Supreme Court decisions discussed in this Artiele involve disputes over the ownership of real property. There are of course dozens of cases in the state courts that do not reach the Supreme Court. A perusal of the Eighth Dicennial Digest, covering the years 1966 through 1976, and West's General Digest, 5th Series, revealed 31 cases in which contested claims to property were the principal dispute; there were many other cases in which a dispute over property was one of a number of contested issues. Recent state court decisions concerning church 
congregations over whether a minister should be fired, ${ }^{5}$ a church building replaced, ${ }^{6}$ or a member expelled. ${ }^{7}$ Many of these cases involve allegations of procedural defects, ${ }^{8}$ such as inadequate notice, ${ }^{9}$ in the conduct of the local church meeting at which the decision on the disputed matter was inade. Courts are sometimes also asked to review allegations that church officials have breached their fiduciary obligations in their handling of church property. ${ }^{10}$

The Supreine Court has been obscure about the constitutional difficulties presented by these cases. It has sometimes struck down state practices without identifying which rehgion clause-free exercise or estabhishment-was offended. At other times it has overturned state actions without mentioning the religion clauses at all, relying instead on

property disputes include Presbytery of Riverside v. Community Church, 89 Cal. App. 3d 910, 152 Cal. Rptr. 854 (2d Dist.), cert. denied, 444 U.S. 974 (1979), and Protestant Episcopal Church v. Graves, 161 N.J. Super. 230, 391 A.2d 563 (1978), affd, 83 N.J. 572, 417 A.2d 19 (1980), cert. denied sub nom. Moore v. Protestant Episcopal Church, 101 S. Ct. 954 (1981).

5. These are perhaps the most common. See, e.g., Abyssinia Missionary Baptist Church v. Nixon, 340 So. 2d 746 (Ala. 1977); In re Galilee Baptist Church, 186 So. 2d 102 (Ala. 1966); Williains v. Joues, 61 So. 2d 101 (Ala. 1952); Rush v. Yancy, 233 Ark. 833, 349 S.W.2d 337 (1961); Providence Baptist Church v. Superior Court, 50 Cal. 2d 55, 251 P.2d 10 (1952); Burnett v. Banks, 130 Cal. App. 2d 631, 279 P.2d 579 (1st Dist. 1955); Epperson v. Meyers, 58 So. 2d 150 (Fla. 1952); Manguin v. Swearingen, 565 S.W.2d 957 (Tex. Civ. App. 1978); First Baptist Church v. Giles, 219 S.W.2d 498 (Tex. Civ. App. 1949).

6. See, e.g., Miller v. McClung, 4 Mich. App. 714, 145 N.W.2d 473 (1966); Hopewell Baptist Church v. Gary, 111 N.J. Super. 1, 266 A.2d 593 (App. Div.), aff d, 57 N.J. 166, 270 A.2d 409 (1970).

7. See, e.g., Abyssinia Missionary Baptist Church v. Nixon, 340 So. 2d 746 (Ala. 1977); Rush v. Yancy, 233 Ark. 883, 349 S.W.2d 337 (1961); Epperson v. Meyers, 58 So. $2 d 150$ (Fla. 1952); Sapp v. Callaway, 208 Ga. 805, 69 S.E.2d 734 (1952); Nelson v. Ellis, 140 So. $2 d 194$ (La. App. 1962); Baugh v. Thounas, 56 N.J. 203, 265 A.2d 675 (1970); Bear v. Reformed Mennonite Church, 462 Pa. 330, 341 A.2d 105 (1975); Mangum v. Swearingen, 565 S.W.2d 957 (Tex. Civ. App. 1978); David v. Carter, 222 S.W.2d 900 (Tex. Civ. App. 1949); First Baptist Church v. Giles, 219 S.W.2d 498 (Tex. Civ. App. 1949).

8. E.g., In re Galilee Baptist Church, 186 So. 2d 102 (Ala. 1966) (involving defects in the conduct of the meeting); Konkel v. Metropolitan Baptist Church, 117 Ariz. 271, 572 P.2d 99 (App. 1977); Burnett v. Banks, 130 Cal. App. 2d 631, 279 P.2d 579 (1st Dist. 1955) (involving a claim that elections for director had not been held as required by church rules).

9. E.g., Hopewell Baptist Church v. Gary, 111 N.J. Super. 1, 266 A.2d 593 (App. Div.), affd, 57 N.J. 166, 270 A.2d 409 (1970); Nelson v. Ellis, 140 So. 2d 194 (La. App. 1962); David v. Carter, 222 S.W.2d 900 (Tex. Civ. App. 1949).

10. Such charges nuay be brought by church ineinbers, as in Providence Baptist Church v. Superior Court, 40 Cal. 2d 55, 251 P.2d 10 (1952), and Greater Pleasant Green Baptist Church v. Robertsou, 343 So. 2d 239 (La. App. 1977). They may be the source of a dispute that comes to court framed as a battle over churclı procedures. See, e.g., Abyssinia Missionary Baptist Church v. Nixon, 340 So. $2 \mathrm{~d} 746$ (Ala. 1976). They may also be brought by state governmental authorities enforcing charitable trust rules, see People v. Christ Church of the Golden Rule, 79 Cal. App. 2d 858, 181 P.2d 49 (2d Dist. 1947), and by the federal authorities concerned about the misnse of fcderal funds, see In re Grand Jury Subpoena Upon Rabbinical Seminary Netzach Israel Ramilis, 450 F. Supp. 1078 (E.D.N.Y. 1978), or enforcing other federal regulatory scheines concerned with frauduleut acts, see SEC v. World Radio Mission, Inc., 544 F.2d 535 (1st Cir. 1976), disapproved in Aaron v. SEC, 446 U.S. 680 (1980). 
vague references to the first amendment. ${ }^{11}$

Perhaps the difficulty is that the problem seems too obvious. A court drawn into an imternal religious dispute will surely become "entangled" 12 in church affairs. Judicial authority will be brought to bear on a religious matter in which the state has no apparent secular interest. ${ }^{13}$ Almost any church dispute can be characterized as doctrinal, and it seems self-evident that the religion clauses forbid secular authorities from making pronouncements identifying the true doctrine. There could hardly be inore certain markers of the "forbidden domain."14 The mdependence of churches and the religious freedom of their members are apparently endangered by intervention.

Internal religious disputes, lowever, unlike other religion cases, do not involve a meddlesome government gratuitously inserting itself into church affairs. They are requests by one faction of the church-soinetimes by both factions ${ }^{15}$ - that the court act as referee. The stakes may be distinctly secular, as where property is concerned. Moreover, almost all cases involve the kind of dispute that the court would norinally decide in the context of a secular nonprofit association and imvolve rights ordinarily rccognized under corporation, contract, or trust law.

What should a court do when faced witli such a dispute? If it decides that the religion clauses call for completc autonomy for the rehgious organization, it will refuse to hear the dispute, granting the

11. In Presbyterian Church v. Hull Church, 393 U.S. 440, 449 (1969), the Court at one point uses the words "free exercise" and "establish" in an obvious allusion to the religion clauses, but no direct mention of them occurs in the opinion. In Serbian E. Orthodox Dioccse v. Milivojevich, 426 U.S. 696 (1976), the Court does not even engage in allusions, but is content with the most general assertions that the "First and Fourteenth Amendments" bar civil courts from reviewing the decisions of hierarchical authorities.

12. The requirement that government authorities avoid "excessive entanglement" is a well established part of the doctrine of the religion clauses. See Roemer v. Maryland Public Works Bd., 426 U.S. 736, $762-67$ (1976) (state aid to church affiliated colleges); Lemon v. Kurtzman, 403 U.S. 602, 614-25 (1971) (state aid to supplement teachers' salaries im church-affiliated schools); Walz v. Tax Comm'n, 397 U.S. 664, 674-80 (1970) (property tax exemption for rehgious organizations); L. TRIBe, American Constitutional LaW 865-80 (1978).

13. Legislation affecting religious organizations is unconstitutional unless: "First, the statute must have a secular legislative purpose; second, its principal or prinary effect inust be one that neither advances nor inhibits religion . . ." Lemon v. Kurtzman, 403 U.S. 602, 612 (1970) (quoting Board of Educ. v. Allen, 392 U.S. 236, 243 (1968)). See Epperson v. Arkansas, 393 U.S. 97, 107-09 (1968) (law prohibiting teaching of evolution in state supported schools). The existence of a secular purpose for government action has been described as "the most fundainental requirement in the constitutional system designed to secure refigious autonomy." L. TRIBE, supra note 12 , at 835 .

14. The religious views espoused by respondents might seem incrcdible, if not preposterous, to most people. But if those doctrines are subject to trial before a jury charged with finding their truth or falsity, then the same can be done with the religious beliefs of any sect. When the triers of fact undertake that task, they enter a forbidden domain. United States v. Ballard, 322 U.S. 78, 87 (1944).

15. This was the case in Serbian E. Orthodox Diocese v. Milivojevich, 426 U.S. 696, 725-26 (1976) (Rehnquist, J., dissenting). 
organization immunity from judicial dispute resolution. The price of immunity, however, is denying church members ordinarily available remedies, solely on account of the religious nature of the organization in which the corporation, contract, or trust dispute arose. When a court refuses to adjudicate church disputes, it may sacrifice members' contractual interests and religious freedoin. Immunity froin judicial dispute resolution nuay also burden the organizational efforts of rehgious groups by denying them the benefit of secular rules that facilitate the creation and growth of private, voluntary associations. There is thus a tension between autonomy for the church and some of the very values that such autonomy might at first be assumed to further. This tension colors the constitutional question differently than appears on mitial examination. ${ }^{16}$

This Article suggests a resolution to this tension. In so doing, the Article assumes that the goal is a religiously neutral adjudication: one that neither advances nor retards a church faction on the basis of its religious views. ${ }^{17}$ The alternative of a religiously-based adjudicationone whicl favors a faction on the basis of its religious beliefs-is unlikely to meet constitutional requirements. The only otlier alternative is to refuse to decide church disputes, an approach tliat would satisfy the goal of avoiding entanglement at the price of meinbers' rights and churcli organizing ability. This Article shows why a religiously neutral adjudication is normally possible, inaking it unnecessary to pay the price of abstention.

Part I of this Article traces the failure of the Suprene Court to develop a religiously neutral doctrine. It long ago began down a different path altogether. Since its 1871 decision in Watson $v$. Jones, ${ }^{18}$ the Supreme Court, as well as inost state courts, has assunied that the judiciary could intervene more freely to settle disputes in "congregational"

16. This tension has also been observed in L. TRIBE, supra note 12, at 881-85: "[T]he freedoin and autonoiny . . . [to] associate have been circumscribed by government (including judicial) interventions calculated to protect both external public interests and internal private rights." Id. at 881-82.

17. This approach recalls the "neutrality theory" of P. KURLAND, RELIGION AND THE LAW (1962). That conception, designed to reconcile what could otherwise be the conflicting deinands of the free exercise and establishment clauses, has never been adopted by the Court. In its strict form, the neutrality theory would bar any government action based upon religious classifications, an approach that soine have found impractical since even neutral government actions inay, in fact, impose greater burdens on soine religions. See L. TRIBE, supra note 12, at 821.

Unlike inany other cases arising under the religion clauses, cases of internal clurch disputes do not suggest any tension between the establishment and free exercise clauses. If there is something constitutionally defective about a court's involvenent in a churcli dispute, it will be defective on both free exercise and establishment grounds. If the court's response to the dispute improperly establishes an official view, then it will also necessarily impinge on the free exercise rights of the faction or factions with whoin the court disagreed.

18. 80 U.S. (13 Wall.) 679 (1871). 
churches than in "hierarchical" churches. ${ }^{19}$ Under this traditional analysis, courts have often held that there is a rule of deference to the decisions of the central hierarchies that effectively bars any review of their decisions. The Supreme Court cases do not, however, support any unitary rule of deference to hierarchical church authorities. Rather, the Court has employed a number of different rationales from case to case, in a groping and not entirely consistent fashion that has contimued through its most recent decision, Jones $v$. Wolf..$^{20}$ The Court's inconsistency follows from its failure to develop a doctrine that relates logically to the genume constitutional concerns presented by these cases.

Part II of this Article proposes a religiously neutral approach that meets constitutional concerns. It demonstrates that the traditional emphasis on classifying churches as congregational or hierarchical has been a critical stumbling block in resolving the court's proper role. It argues that a court should focus on the function that it is asked to perform in adjudicatimg the internal dispute, rather than the type of church before it. Since the constitutional issue in the adjudication of church disputes is the allowable scope of judicial intervention, it makes eminent sense to focus on the nature of that intervention.

Whether the dispute involves a church, social club, or publicly

19. While the distinction between the two categories may not always be clear, the essential difference in the Court's view is that the hierarchical church has a central authority to which local congregations are subject, while in the congregational church there is no authority over the local congregation. See id. at 722-23; Maryland \& Virginia Eldership of the Churches of God v. Church of God, Inc., 396 U.S. 367, 369 n.1 (1970) (Brennan, J., concurring). The extent of central church authority may vary, of course; it nnight include final power over doctrinal matters, and a role in the selection of clergymen for the local congregation. On the other hand, while congregational churches unay have national denominational associations, those are merely voluntary vehicles for such joint action as the member churches may wish to participate $\mathrm{m}$, and have no ecclesiastical or secular authority over the local congregations. The Baptists are probably the most numerous denomination with a congregational pohty, and courts have repeatedly treatcd Baptist churches as congregational for the purpose of this constitutional doctrinc. E.g., Konkel v. Metropohtan Baptist Church, 117 Ariz. 271, 572 P.2d 99 (App. 1977); Miller v. McClung, 4 Mich. App. 714, 145 N.W.2d 473 (1966); Nelson v. Ellis, 140 So. 2d 194 (La. App. 1962). Yet, as developed im the text accompanying notes $85-86$ infra, the line between hierarchical and congregational churches is anything but clear, and in at least one case, an association of Baptist churches has been found to be hierarchical. Crumbley v. Solomon, 243 Ga. 343, 254 S.E.2d 330 (1979). See Western Conference of Original Free Will Baptists v. Creech, 256 N.C. 128, 123 S.E.2d 619 (1962).

Most other large Protestant denominations as well as the Roman Catholic Church are hierarchical in structure. At various times the Presbyterian Church, the Methodist Church, and the Lutheran Church have all been held to be hierarchical for the purpose of this doctrine. Lowe v. First Presbyterian Church, 56 Ill. 2d 404, 308 N.E.2d 801, cert. denied, 419 U.S. 895 (1974) (United Presbyterian Church); Hoffman v. Tieton View Community Methodist Episcopal Church, 33 Wash. 2d 716, 207 P.2d 699 (1949) (Methodist Church); Immanuel Evangehical Lutheran Church v. Fromm, 367 Mich. 575, 116 N.W.2d 766 (1962) (Evangelical and Reformed Clurch). In the case of the Lutheran Church, however, the courts have gone both ways. See the cases collccted by Kauper, Church Autonomy and the First Amendment, in Church and STATE, Supreme Court AND THE FIRST AMENDMENT 91 n.75 (P. Kurland ed. 1975).

20. 443 U.S. 595 (1979). 
traded business corporation, there are essentially two possible functions that judicial intervention may serve. First, the court may be asked to construe and apply the organization's own internal agreements, as reflected in its articles of incorporation, bylaws, or contracts: Was the measure passed by the margin required in the bylaws? Was expulsion of a member proper under the terms of his contract with the group? This is the "contract function." Courts ordimarily perform the contract function by applying what I call the contract principle; that is, they enforce the parties' agreeinent. Since a court is deciding only the intentions of the parties and not imposing externally created rules or policies, ${ }^{21}$ the contract principle offers the promise of a religiously neutral basis for adjudication. Part II examines the contract function and explams how the use of the contract principle permits a court to settle church disputes involving that function within the limits set by the religion clauses.

Besides being asked to construe and apply the organization's own interual agreements, the court inay be called upon to impose externally generated rules - either statutory or judge-made - on the organizations: Were the directors notified of the ineeting as required by statute? Did their action constitute a breach of trust under primciples derived froin the cases? This is the "rulemaking function." The rulemaking function has a greater potential for constitutional problems than the contract function. Part III examines the most cominon cases that appear to involve rulemaking in religious disputes and concludes that most of thein can be resolved by reliance on the contract primciple. While a few intractable cases involving rulemaking remain, this Article concludes that most internal church disputes can be constitutionally adjudicated without resorting to special doctrines of judicial deference or abstention.

\section{I \\ Development of the Traditional Doctrine}

\section{A. Watson v. Jones}

The hiterature of church disputes contains repeated references to the 1871 Supreme Court decision in Watson v. Jones. ${ }^{22}$ Watson involved a local congregation in Louisville, called the Walnut Street Presbyterian Church. The congregation had divided into two factions

21. In one sense, of course, this distinction is too simplistic; courts obviously employ externally generated rules in contract disputes as well. There are rules that guide the court in determining what the agreement is, or prescribe with particularity the method by which it must be formed in order to be enforceable. Such rules are designed to aid the court in accurately determining the existence and content of an agreement. These standard contract primciples for the most part create no special difficulties when applied to church disputes. See text accompanying notes 113-74 infra.

22. 80 U.S. (13 Wall.) 679 (1871). 
during the Civil War. A majority of the congregation's ruling "elders" were of the proslavery faction, while a majority of the church members were of the antislavery faction. The antislavery faction, with the support of the central Presbyterian Church, chose new elders, but the incumbents refused to recognize them. An action was brought to oust the proslavery elders from their control over the church property. The proslavery faction had meanwhile joined forces with sympathizers in other congregations to form the Presbyterian Church of the Confederate States, the hierarchy to which this faction now claimed allegiance. They rejected the original hierarchy, claiming that it had abandoned the "true" Presbyterian faith. ${ }^{23}$

The issue in Watson was control over the property of the Wahrut Street church, but its facts raised almost every question that arises in court adjudication of church disputes: In this fight between competing sets of "elders," what weight should the court give to the hierarchy's endorsement? Which hierarchy? Should a court consider the claim that the origmal hierarchy's departure from the faith robbed it of its authority? Were the new, antislavery elders properly chosen under church rules? Should a court examine those rules to decide whether the new elders were in fact entitled to office?

The Court avoided most of these questions with a narrow ruling. It held that by setting up the competing hierarchy, the proslavery elders withdrew froin the church and therefore abandoned any property rights in it which they might have had. ${ }^{24}$ This conclusion led to a decision for the antislavery faction of the local church, and implied as well that the origmal hierarchy had not been supplanted. Although logic required no further elaboration, the Court took the opportunity presented by the case to treat the entire question of church disputes in a comprehensive fashion.

Because Watson reached the Court as a pre-Erie diversity case, the discussion was not limited to constitutional considerations. The result was an influential statement of general principles, many of which have since been constitutionalized. But because of the opimion's rambling character, it is possible to read sonie portions of it as standing for propositions imconsistent with those advanced in other portions, and later courts have been able to pick the parts that suit them. Four basic propositions in Watson have had such a continuing life.

\section{Congregational Churches: Ordinary Voluntary Associations}

The first proposition is rather straightforward: Disputes between

23. Id at 712-13.

24. Id. at 734 . 
factions of congregational churches "must be determined by the ordinary principles which govern voluntary associations." 25 Watson clearly contemplated courts performing the contract function in such cases, and performing it by application of ordinary contract rules. It assumes, for example, that the court might examine church documents to decide whether a particular decision may be made by the officers of the church, or whether it requires a vote of the congregation.

The Supreme Court has only once reviewed a dispute within a congregational church, and that was in the year after Watson. The case, Bouldin v. Alexander, ${ }^{26}$ followed Watson's "voluntary association" approach in setting aside a church election for procedural irregularities, mcluding defective notice. In so doing, the Court seemed not only to be applying rules found in church documents, but also to be performing the rulemaking function, by imposing judicially created standards of fairness in elections. Curiously, Bouldin does not cite Watson. ${ }^{27}$ Nonetheless, it seems to stand for the proposition that courts need no special "religion rules" when deciding cases involving congregational churches.

\section{Hierarchical Churches: Three Deference Principles}

Watson's three remaining principles are intended to apply to hierarchical churches, and it is these three which have caused the difficulties. All three require civil courts to accept as binding the decisions of church authorities in questions of "discipline, faith, ecclesiastical rule, custom, or law."28 But Watson offers three different rationales for this conclusion. These three rationales have generated three principles for handling church disputes.

\section{a. The Contract Principle}

This principle requires a court to sustain hierarchical decisions because "all who unite themselves to such a body do so with an imphed consent to this government, and are bound to submit to it." Watson adds that appeals froin decisions of church tribunals should be allowed when "the organism itself provides." 29 When church ineinbers, by joining the church, have implicitly agreed to be bound by a hierarchy's

25. Id. at 725 .

26. 82 U.S. (15 Wall.) 131 (1872).

27. Other courts have cited Watson for the proposition that disputes between congregational church factions will be reviewed in the same manner as disputes within secular voluntary associations. Although the Supreme Court has not decided any other cases involving congregational churches, it has explicitly rehed on the hierarchical nature, rather than congregational nature, of the churches involved in the cases it has decided. See note 19 supra.

28. 80 U.S. (13 Wall.) at 727.

29. Id. at 727-29. 
decisions, the court will not review those decisions. But the court defers to the hierarchy only because the parties' agreement makes deference appropriate. This approach is consistent with that employed for congregational churches, as well as secular organizations, because it applies the parties' agreement.

\section{b. The Ban on Doctrinal Decisions}

Watson says that a civil court should never decide ecclesiastical questions because "the law knows no heresy, and is committed to the support of no dogma, the establishment of no sect." 30 This is the "ban on doctrinal decisions." While the contract principle looks to the parties' agreement to chart the boundaries of required deference to church authority, the ban on doctrinal decisions looks to the subject matter of the dispute. Under this principle the courts must accept the hierarchy's decisions on ecclesiastical matters because substantive decisions on rehgious doctrine are beyond the courts' proper realm, and thus nonreviewable. The ban on doctrinal decisions gives the courts a more limited ambit than the contract principle, since it would deny review whenever the dispute could be characterized as doctrinal, even where the parties had an unambiguous agreement which, if enforced, would decide the dispute.

\section{c. Strict Deference}

This final principle from Watson assumes that there is some overriding concern for rehgious autonomy that cannot be successfully satisfied if doctrine and contract form the only limits on judicial intervention. Strict deference looks neither to the parties' agreement nor to the subjcct matter of the dispute. Its greatest significance is in claims that a hierarchy's decision exceeded the scope of its authoritywas beyond the hierarchy's "jurisdiction," so to speak-and in claims that the process employed in rendering the decision violated church procedural rules. It requires the court to defer to the hierarchy even when challengers inake such jurisdictional or procedural objections to its decisions.

The strict deference principle is thus significantly different froin the other principles enunciated in Watson. It conflicts with the contract principle, which is founded on the partics' "consent to be bound." Under the contract principle, mquiry into the scope of the consent might be critical, and thus a court could ask whether the decision in question was withm the hierarchy's agreed authority-was withm its jurisdiction. Nor does strict deference follow from the ban on doctrinal 
decisions, which would only prohibit review of the substance of theological matters rather than the jurisdiction to decide them. For example, under the ban on doctrinal decisions, courts could not review the substance of a hierarchical determination of the morality of abortion, yet could consider a claim that church law preserves to local congregations the right to choose their minister. Watson itself recognized that strict deference is inconsistent as well with its approach for congregational churches, in which a civil court could entertain a challenge based upon procedural or jurisdictional defects. The explanation for this difference, according to Watson, is that for hierarchical churches (but presumably not for congregational churches), deciding procedural or jurisdictional claims requires judicial decision "of all ecclesiastical questions."31

This brief synopsis reveals that Watson does not stand for any one principle. It is rather a many-splendored precedent. The merits of its contract approach to congregational churches have never been re-examined by the Supreme Court, although the contract principle has been followed in dozens of state court decisions. ${ }^{32}$ But in the century following Watson, the Court has decided eight cases involving disputes in hierarchical churches, giving it ample opportunity to clarify its views. While these cases gradually constitutionalized the issues, they did not clarify their resolution. They instead reveal an uneasy Court, shifting back and forth among the alternate principles Watson offers.

\section{B. Developments After Watson}

The Supreme Court did not hear a sequel to Watson until the 1929 case of Gonzalez v. Archbishop..$^{33}$ The plaintiff in Gonzalez was a tenyear-old who complained that he had not been appointed to a chaplaincy that had been created by the will of one of his ancestors and had always been given to his family. Appointment of the plaintiff would have violated Roman Catholic canon rules setting forth the qualifica-

31. [I] the civil courts are to inquire into all these matters, the whole subject of the doctrinal theology, the usages and customs, the written laws, and fundamental organization of every religious deuomination may, and inust, be examined into with minuteness and care, for they would becone, in almost every case, the criteria by which the validity of the ecclesiastical decree would be determined in the civil court. This principle would deprive these bodies of the right of construing their own church laws, would . . ., in effect, transfer to the civil courts where property rights were concerned the decision of all ecclesiastical questions.

Id. at 733-34.

32. A perusal of the Eighth Dicennial Digest, covering 1966 to 1976, as well as West's General Digest, 5th Series, revealed 43 state court decisions dealing with the question of whether a congregational church had followed proper internal procedures in reaching some challenged decision. For examples of such cases, see notes 5-8 supra. Also see the discussion in Section A of Part III infra.

33. 280 U.S. 1 (1929). 
tions for the post-rules adopted long after the testator had died and not in force at the time of earlier appoimtments. Justice Brandeis, writing for the Court, found that the testator liad not intended to have the chaplaincy forever governed by the cliurcli rules in effect at the time of the will. He found that the testator contemplated that the archbishop would review the applicant's fitness for the chaplaincy, altliough apparently this point was not explicitly covered in the will. Since the terms of the will called for the arclibisliop to ascertain an applicant's fitness, the will also assuined, Justice Brandeis concluded, that the arclibishop would apply contemporary cluurcl standards in conducting his review. ${ }^{34}$

Although lie did not use the term, Justice Brandeis relied on the contract principle in deciding Gonzalez. A will, of course, is not a contract, but in this context it inay serve the same function. It sets the terms under which the testator inade his bequest, and the church accepted it. Those terms, as construed by the Court, rcquired deference to the arclibisliop's determination that the plaintiff was not qualified. Justice Brandeis' rehance on the contract principle was quite exphicit:

In the absence of fraud, collusion, or arbitrariness, the decisions of the proper church tribunals on matters purely ecclesiastical, although affecting civil rights, are accepted im hitigation before the secular courts as conclusive, because the parties in interest made them so by contract or otherwise. Under like circumstances, effect is given im the courts to the determinations of the judicatory bodies estabhished by clubs and civil associations. $^{35}$

In Gonzalez, the contract principle called for deference to the decision of the cliurcl hierarchy. This result is not based on any special rule for judicial resolution of cliurcli disputes, however. It is based on the same principle of restramt that would apply to any private association: judicial deference to a substantive decision made by a properly constituted associational body where it acted within the scope of its autlority. The court was treating the church no differently than it would a private club.

Justice Brandeis applied to churches the general rule that corporate or associational bylaws are construed according to the sane primciples that govern the construction of contracts generally. ${ }^{36}$ Under this approacl, the scope of permissible judicial involveinent should be determined by reference to the governing instruments of the association in question, as well as any other sources that record the agreenent of

34. Id. at 17.

35. Id at $16-17$.

36. This approach is applied to nonprofit corporations as well as business corporations. See, e.g., American Center for Educ. v. Cavnar, 26 Cal. App. 3d 26, 32, 102 Cal. Rptr. 575, 580 (2d Dist. 1972). 
the members. Justice Brandeis' other qualification in Gonzalez- "in the absence of fraud, collusion, or arbitrariness"-also seems to follow from the use of contract principles. A court should always be available to determine whether an organizational decision has been made im the manner contemplated by the agreement, for otherwise the member could not be said to be bound by it. Few agreements would contemplate decisions made fraudulently or arbitrarily.

Justice Brandeis' logic leaves no room for special treatment of hierarchical churches. The hierarchy's decisions would be enforceable when the church's governing structure made them so, with the necessary imphication that a court could decide what the understood governing arrangements are. Lower courts, however, ignored this possible construction of Gonzalez and continued to distinguish their method of resolving disputes im hierarchical churches from that for congregational churches. ${ }^{37}$ Perhaps the message was too subtle, coming as it did in the context of a rather smgular dispute over a chaplaincy, rather than the more typical contest over property. And although the logic of Gonzalez followed the contract principle, it did sustain the hierarchy's decision. The result was thus no different than if strict deference or the ban on doctrinal decisions had been the basis for the decision. It was therefore possible to treat the contract language in Gonzalez as dicta, as indeed it ultimately was by the Supreme Court. The doctrinal potential of Gon$z a l e z$ was thus never realized, and its endorseinent of the contract principle was eventually overruled. ${ }^{38}$

The Court's next church case came in 1952, when it reviewed Kedroff v. St. Nicholas Cathedral ${ }^{39}$ Kedroff involved a dispute between the Moscow-based central hierarchy of the Russian Orthodox Church, and the American diocese. The prize was control of St. Nicholas Cathedral in New York City. During most of its history, from the sixteenth century to the present, the Russian Orthodox Church has been governed by a central hierarchy and headed by a patriarch. In 1917, Tikhon, the fornner American archbishop, was chosen as patriarch by a "sobor," or church convention. Tikhon quickly became embroiled in a dispute with the new Bolshevik governinent. It was suggested that he had engaged in counterrevolutionary activity, and he was imprisoned. At the end of 1920, Patriarch Tikhon issued a "ukase" relatimg to "church administration for troublesome times." 40 It granted the American diocese considerable autonomy while the Rus-

37. See, eg., First English Evangelical Lutheran Church v. Dysinger, 120 Cal. App. 139, 6 P.2d 522 (1st Dist. 1931); Partin v. Tucker, 126 Fla. 817, 172 So. 89 (1937); St. Micliael's Ukranian Greek Catholic Cliurch v. Bohachewsky, 60 R.I. 1, 196 A. 796 (1938).

38. See text accompanying notes 60-61 infra.

39. 344 U.S. 94 (1952).

40. Id. at 103. 
sian hierarchy "was unable to function, subject to confirmation later to the Central Church Authority when it is reestabhished."41 An American sobor held in Detroit in 1924 essentially declared independence from the Russian hierarchy until such time as a "legally convoked, legally elected" sobor of the entire church was held, with participation of the American church, and "under conditions of pohtical freedom."42 A tradition of American autonomy was thereby established in what previously had been a hierarchical church. Tikhon died in 1925, his ukase apparently still in effect.

The Russian central church and the Communist government ultimately reached an accord. A new sobor of the entire church was held in Moscow im 1945, and representatives of the American branch attended. This sobor, which the Kedroff Court states was recognized as "a true sobor" by all parties to the litigation, chose a new patriarch, Alexi. Alexi met with the American representatives, and set forth his requirements for reunion, which included an agreement by the American church to abstain "from political activities against the U.S.S.R." 43 The American church rejected the offer, but the revived Russian hierarchy pressed their claims of authority. When the American church resisted, the focus of the dispute became control over St. Nicholas Cathedral in New York City. The cathedral was in the possession of Benjamin, who was loyal to Alexi, the new patriarch. Benjamin claimed to be Archbishop of North America by virtue of his appointment in 1933 by the Moscow hierarchy, whose legitimacy the American church had rejected under the authority of the Tikhon ukase. Benjamin's possession of the cathedral was challenged by Leonty, whose claim was based on his appoimtment by the American church as Archbishop of New York. It thus seemed that to settle the dispute a court would need to determine which appointing authority was legitimate.

The New York Legislature intervened on behalf of the American church by aunending the Rehigious Corporation Law to specify that the American branch controlled the title-holding corporation. Relying on this legislation, the New York courts held that Leonty was entitled to possession of the cathedral. The issue before the Supreme Court in Kedroff was thus the constitutionality of the New York enactment. New York sought to justify the enactment as necessary to free the American church from control by a foreign government with a hostile attitude "toward things religious." 44 It was argued that only with inde-
41. Id.
42. Id at $103-04 \mathrm{n} .8$.
43. Id. at 105 .
44. Saint Nicholas Cathedral v. Kedroff, 302 N.Y. 2, 33, 96 N.E.2d 56, 74 (1950). 
pendence from the Soviet-dominated central hierarchy could the American church remam faithful to the purposes of its religious trust.

The Court found the legislature's intervention improper because it interfered with the free exercise of religion. Quoting extensively from Watson, the Court characterized the dispute before it as involving the selection of clergy, which "must now be said to have federal constitutional protection." 45 Yet the central problen was identifying who had this constitutionally protected authority to make the selection. The Court disposed of that issue in two scattered sentences. The question was "strictly a matter of ecclesiastical government," and there was no dispute that the Moscow hierarchy had the appointment power "prior to the Russian Revolution."46 Since nothing in the record "mdicates a relinquishment of this power by the Russian Orthodox Church,"47 the Court concluded that the statute unconstitutionally imtruded into the conduct of church affairs.

It is difficult to discern precisely which strand of Watson the Kedroff court was applying. The contract principle would call for an examination of whether the hierarchy had retained or renewed its appointive authority under church rules, but that inquiry was not made. The Court's assumption that the hierarchy had not given up any power is erroneous under the facts as described by the Court itself; the Tikhon ukase was an exphicit relinquishment. The Court also ignored the argument that the American church's acceptance of the 1945 sobor implied an acceptance of the new patriarch, as well as an acknowledgement that the "troublesome times" had ended, and that Tikhon's 1920 ukase was thus no longer in effect. Simce the Court did not find that the American church had acquiesced to the new patriarch's legitimacy, it would seem, under the contract principle, that the Court should have determined whether Alexi was a legitimate patriarch who could reassert the powers relinquished under the terins of the 1920 ukase. Was the hierarchy now "able to function," free from interference by an antirehgious government? The Court's indifference to this entire line of imquiry implies that the contract principle was not the basis of its decision. Rather, it would seem that the strict deference principle of Watson, with its refusal to consider claims that the hierarchy lias acted beyond the scope of its jurisdiction or in violation of estabhished procedures, was the governing rule. Indeed, if anything, the Court may have apphed an expanded strict deference principle by foreclosing inquiry even into whether the body asserting claims of hierarchical authority is in fact the hierarchy.

45. 344 U.S. at 116.

46. Id. at 115 .

47. Id at 120. 
This last reading of Kedroff is supported by the Court's treatment of its sequel, Kreshik v. St. Nicholas Cathedral, decided in $19600^{48}$ After Kedroff, New York's Court of Appeals sent the case back for retrial, instructing the lower court to determine whether the Moscow ecclesiastical authorities were "mere puppets of a monolithic and atheistic secular power."49 The New York court thus seemed to follow a contract approach in determining whether the conditions of independence specified in the Tikhon ukase still prevailed. But to the chagrin of the New York Court of Appeals, the trial court found in the Russian's favor. The court of appeals then reversed the trial court, in an opinion perhaps too fervently anti-Communist in tone to reassure one of the forum's neutrality. ${ }^{50}$

In a two-page per curiam, the United States Supreme Court once again reversed, observing merely that "the decision now under review rests on the same premise which was found to have underlain the enactment of the statute struck down in Kedroff." 1 Although the opinion is excessively taciturn, apparently the invalid premise is that the government, whether legislatively or judicially, could itself determine the extent of the new patriarch's authority. The strict deference principle thus prevailed. The contract analysis of Gonzalez was forgotten.

Kedroff and Kreshik were certainly not the last word, however. In 1969, the Court decided the well-known case of Presbyterian Church in the United States v. Hull Memorial Presbyterian Church, ${ }^{52}$ a dispute between the central church and a Georgia congregation over whether the central church had departed fron fundamental Presbyterian tenets. In Hull, the Court enthusiastically revived the third Watson thread, the ban on doctrinal decisions, although in dicta the Court also seemed to endorse the contract principle.

Under Georgia case law, when the local congregation of a hierarchical church held title to the church property, a trust in favor of the mother church was automatically implied. State law also provided that one terin of this implied trust was that the mother church continue to adhere to the religious behefs prevailing at the time of the local congregation's affiliation. The local church in Hull sought to withdraw from the central church, and to retain the property, arguing that the mother church had lost the benefit of the trust because it had abandoned fundainental Presbyterian tenets and thus departed from the trust require-

48. 363 U.S. 190 (1960).

49. Saint Nicholas Cathedral v. Kedroff, 306 N.Y. 38, 51, 114 N.E.2d 197, 205 (1953). (1959).

50. Saint Nicholas Cathedral v. Kreshik, 7 N.Y.2d 191, 164 N.E.2d 687, 196 N.Y.S.2d 655

51. 363 U.S. at 191.

52. 393 U.S. 440 (1969). 
ments. In order to decide whether the central church or the local congregation owned the property, the Georgia jury was instructed to determine whether the central church, by ordaining women, supporting the National Council of Churches, and opposing bible reading in the public schools, had departed from the faith. The jury returned a verdict for the local church, and the trial court enjoined the hierarchy from interfering with the local's control of their property. The judgment was affirmed by the Georgia Supreme Court, ${ }^{53}$ but the United States Supreme Court reversed.

The Court's opinion again quotes from Watson, but this tinie relying on the ban on doctrinal decisions. The constitutional defect with Georgia's rule, according to the Court, was that it required the civil tribunal to decide questions of theology, in violation of the religion clauses of the first amendinent. But while emphasizing the need to avoid substantive review of ecclesiastical questions, the court also recognized the contract principle of Gonzales. It quoted Gonzalez' contract language, includimg its authorization of court review of church decisions for "fraud, collusion or arbitrariness," and tlien went one step further. The courts could adjudicate church property disputes, the Court explaimed, if they employed "neutral principles of law, developed for use in all property disputes." 54 It poimted out that the defective Georgia rule did not call for such permissible review of clrurcl decisions, but required instead the forbidden civil court determination of doctrinal matters. The "neutral principles" statement is dicta, since the decision in Hull relied only on the ban on doctrinal decisions. Yet it is hard to reconcile the Court's approving reference to Gonzalez and neutral principles with the decisions im Kedroff and Kreshik. It seemed that the Court was again changing course sub silentio. ${ }^{55}$

An ambiguous start by the Court in Watson was followed by use of the contract principle in Gonzalez, apparent endorsement of strict deference in Kedroff and Kreshik, and application of the ban on doctrine decisions in Hull. One year after Hull, a brief per curiam decision repeated Hull's emphasis on the avoidance of doctrinal decisions as the principal limitation on judicial action. ${ }^{56}$ But the Court clranged course

53. Presbyterian Church v. Mary Elizabeth Blue Hull Memorial Presbyterian Church, 224 Ga. 61,159 S.E.2d 690 (1968).

54. 393 U.S. at 449.

55. Justice Brennan's opinion for the Court actually cites Kedroff and Kreshik in support of his analysis, but without any rcal explanation of what those cases held. Id at 447-49. One commentator stated after $H u l l$ that "it may safely be predicted that future hitigation will furnish a rich glossary on 'fraud, collusion, or arbitrariness.' " Kauper, supra note 19, at 94. In hight of the decision in Milivojevich, discussed infra, that glossary was never developed.

56. Maryland and Virginia Eldership of the Churches of God v. Church of God, Inc., 396 U.S. 367 (1970). This case was also a property dispute between the central church authority and two local congregations that decided to withdraw. The Supreme Court sustained Maryland's ad- 
again in Serbian Eastern Orthodox Diocese v. Milivojevich, ${ }^{57}$ decided in 1975. In Milivojevich, the Court retreated from Hull's promise of future application of contract principles.

Milivojevich, like Kedroff, involved the American branch of a hierarchical church whose leadquarters lay in a Communist country, this time Yugoslavia. Bishop Milivojevich had been the head of the American branch of the Serbian Eastern Orthodox Church until he became embroiled in a dispute with the mother church. In an arguinent somewhat reminiscent of that in Kedroff, the bishop claimed that the dispute grew out of his opposition to the hierarchy's dommation by the Coinmunist government. ${ }^{58}$ The inother cliurch dealt witl the dispute by removing and defrocking Milivojevich, and by dividing the American diocese into three separate districts. The ousted bisliop brought a state court action seeking restoration of the single diocese, reinstatement as its bishop, and control over the clurch corporation that managed its secular affairs. Although the central church won in the trial court, the Illinois Supreme Court found for Milivojevich. ${ }^{59}$ It lield that his ouster was invalid because it was not carried out in accord with church rules, and that the division of the American diocese into three separate branches was beyond the authority of the inother church, as that authority was described in the internal governing documents. This case thus presented a direct application of the contract principle suggested in Watson, Gonzalez, and Hull.

Milivojevich was a particularly appropriate case in which to apply contract principles because there was real evidence of a contract. The American diocese liad existed as an independent body before its affiliation with the mother churcl, and was the only diocese with its own constitution, a result of the events surrounding its decision to affiliate. The claim that this constitution, which had been approved and ac-

judication, which had relied upon supposedly neutral state statutory provisions concerning religious corporations, as well as language in the clurch deeds, corporate charters, and the relevant provisions of the central church constitution. The Maryland decision clearly involved the application of contract principles, but the Court's per curiam decision found no problem in Maryland's action because its "resolution of the dispute involved no inquiry into religious doctrine." Id. at 368. Justice Brennan authored a brief concurrence to this per curian decision, joined in by two other unembers of the Court, which foresliadowed the next change of doctrine by its emphasis on the strict deference strand of Watson. Id. at 368-70.

57. 426 U.S. 696 (1975).

58. The bislop was quite vocal in his criticisun of the church, and at one point published a paunphlet defending himself against the charges brought against him by the church hierarchy. Jack Anderson became enlisted in his clause and wrote a column inaintaining that the charges against Milivojevich were contrived by the Yugoslavian Secret Police and that the new Yugoslavian patriarch who sought to oust the bishop was an agent of the secret police. This is all reported in Note, The Role of Civil Courts in Church Disputes, 1977 Wis. L. REv. 904, 921 n.95.

59. Serbian E. Orthodox Diocese v. Milivojevich, 60 Ill. 2d 477, 328 N.E.2d 268 (1975). 
cepted by the central church, guaranteed certain independence to the American branch in administrative inatters, was thus quite plausible.

The United States Supreme Court, however, reversed the Illinois court. The Court did not rest on a different construction of the organizational docuinents, but rehed instead on the strict deference principle. The Court acknowledged that Gonzalez and Hull provided authority for the Illinois court's analysis. It conceded that the two cases left rooin for review of church dccisions for "fraud, collusion, or arbitrariness," and assumed that a review for arbitrariness would include consideration of whether the church's own rules had been followed. ${ }^{60}$ Justice Brennan's opinion, however, exphicitly rejected the state court's analysis. Instead, the Court decided that it could not question the hierarchy's assertion that its actions were authorized by the organizational agreement and carried out consistently with the church law. The only exception to strict deference apparently left open by Milivojevich was "1nargimal review" for fraud or collusion, and the possibility of such review was not endorsed, but nerely left for later consideration. ${ }^{61}$

Milivojevich's uncompromismg language did not end the Court's waffling, however. Its inost recent decision, Jones $v$. Wolf, ${ }^{62}$ decided in 1979 , indicates that five members of the Court inay have second thoughts about strict deference, even though Milivojevich drew remarkably hittle comment. ${ }^{63}$ Jones approved a limited application of contract principles in judicial decisions involving church disputes. No clear rule has emerged froin Jones, however, because the Court was closely divided and the majority opinion left many questions unanswered.

In Jones, the Court agam dealt with a Presbyterian congregation in Georgia that had decided to declare its independence from the central church. The local congregation was split over the withdrawal, however, and a commission appointed by the hierarchy concluded that the loyal minority faction was the "true congregation." Representatives of that faction brought an action im. Georgia state court to oust the disloyal majority froin their control over the property.

After the reversal in Hull, the Georgia courts abandoned their de-

60. 426 U.S. at 713 .

61. Id.

62. 443 U.S. 595 (1979).

63. The Hull case inspired two articles: Kauper, Church Autonomy and the First Amendment: The Presbyterian Church Case, 1969 Sup. Cr. REv. 347, and Sampen, Civil Courts, Church Property and Neutral Principles: A Dissenting View, 1975 ILL. L.F. 543. Only four pieces have been published since the decision in Milivojevich, however, and three of these were prompted by Jones rather than by Milivojevich. Adams \& Handon, Jones v. Wolf: Church Autonomy and the Religion Clauses of the First Amendment, 128 U. PA. L. REv. 1091 (1980); Note, Judicial Resolution of Church Property Disputes, 31 AlA. L. REv. 307 (1980); Note, Church Property Dispute Resolution: An Expanded Role for Courts After Jones v. Wolf?, 68 GEo. L.J. 1141 (1980); Note, The Role of Civil Courts in Church Disputes, 1977 WIS. L. REv. 904. 
parture-from-trust doctrine and attempted to develop rules based upon the language in Hull suggesting that "neutral principles of law" could be employed to decide church disputes. On remand in Hull, the Georgia courts awarded the property to the local church because there were no property rights reserved to the central church in the relevant deeds. ${ }^{64}$ In a later case involving a similar dispute, Georgia courts found for the central church because the church constitution contamed express language requiring local churches to hold their property in trust for the central hierarchy. ${ }^{65}$ Applying this same test in Jones, the Georgia courts found no language of trust in favor of the hierarchy in the deeds or in the Book of Church Order, the "constitution" settimg forth the governing rules for Presbyterian churches. ${ }^{66}$ The Georgia court therefore concluded that the congregation's majority had absolute title to the church property, and could take it with them when they seceded from the national organization.

The Supreme Court vacated the Georgia court's decision in a five to four vote. ${ }^{67}$ The opinion, written by Justice Blackmun, approved the Georgia court's use of "neutral principles" to decide that the local congregation, and not the mother church, controlled church property. ${ }^{68}$ It remanded the case, however, because the state court did not adequately explain the grounds for its determination that the local congregation should be controlled by the majority faction.

Jones was the first time a Court majority exphicitly recognized the advantages of allowing rehgious organizations to adopt their own organizational structures through deeds, constitutions, or agreements and, of enforcing these arrangements on the same basis as any other private agreements. ${ }^{69}$ The majority's neutral principles doctrine is not the simple application of ordinary contract and trust law principles, however. The Jones Court, seeking to retain Hull's ban on doctrinal decisions, limited the use of contract principles by barring judicial construction of rehigious terns that might be found in the relevant documents. It said a court encountering rehgious terins must follow the interpretation given by the "authoritative ecclesiastical body."70 The Court approved of the Georgia court's application of "neutral principles" because no forbidden interpretation was involved.

64. Presbyterian Church in United States v. Eastern Heights Presbyterian Church, $225 \mathrm{Ga}$. 259, 167 S.E.2d 658, cert. denied sub nom. Presbyterian Church in United States v. Mary Elizabeth Blue Hull Memorial Presbyterian Church, 396 U.S. 1041 (1970).

65. Carnes v. Smith, 236 Ga. 30, 222 S.E.2d 322, cert. denied, 429 U.S. 868 (1976).

66. Jones v. Wolf, 241 Ga. 208, 243 S.E.2d 860 (1978).

67. The four dissenters were Justices Powell, Stewart, and White and Chief Justice Burger.

68. 443 U.S. at 602.

69. Id. at 603 .

70. Id. at 604 . 
The Court was troubled, however, by the Georgia court's assumption that the majority of the congregation controlled the local church. Justice Blackmun said that a state court may employ an initial presumption of majority rule, but must afford some method for rebuttimg it. He approved "any method," so long as it did not "impair free exercise rights" or lead to court entanglement in "matters of religious controversy."71 For example, he suggested that a corporate cliarter that provided for an alternate way of deciding a local church's governance would be adequate to overcome the presumption. He added, however, that "if" Georgia law provided that the will of the local congregation is to be determined according to churcli rules, the courts must defer to the central hierarcliy's decision. ${ }^{72}$

The implication of the "if" in the Court's discussion is that Georgia has the freedom, if it chooses, to declare clurch rules irrelevant to its determination, and to make the presumption of majority rule rebuttable only by some explicit provision in the property deed or corporate charter. On remand, the Georgia court chose to ignore the implication that it need not consider cliurch rules. The court said that the presumption of majority rule could be overcome "by reliance upon neutral status, corporate charters, relevant deeds, and the organizational constitutions of the denomination." 73 It announced that its review "of those sources," presumably includimg the clurch rules contamed in the "organizational constitutions," disclosed no provision rebutting the presumption of majority rule. ${ }^{74}$

Justice Powell's opinion for the four dissenters was faithful to the strict deference principle endorsed in Milivojevich, and rejected "neutral principles" as a feasible alternative. Having determined that the Presbyterian Church has a hierarchical forn of government, and that the local congregation was a member of it, Justice Powell would have deferred to the decision of the hierarchy's tribunal, vestimg control, and thus ownership of the property, in the loyal minority faction. That analysis intentionally ignores any organizational documents or deed language that inight have placed some independent rights in the local congregation, for under strict deference such an mquiry would be irrelevant. Since the mother church had identified the loyal minority as the true congregation, there was no dispute between the congregation and the central church. And the hierarcliy's exclusion of the disloyal majority was of course unreviewable. It is apparent that under strict def-

71. Id at $607-08$.

72. Id at 609 . If Georgia law had provided for a determination under church rules, Jones would have resulted in deference to the hierarchy's determination that the loyal minority group constituted the true congregation. Apphication of strict deference would yield a similar result.

73. Jones v. Wolf, 244 Ga. $388,389,260$ S.E.2d 84,85 (1979).

74. Id 
erence a court would always enforce the hierarchy's view. Although rejected by the majority, this extreme result is probably a correct application of Milivojevich.

The decision in Jones makes it difficult to know just what latitude civil courts are now permitted in resolving church disputes. While the Jones majority clearly appreciated the appeal of decision rules based on ordinary contract and trust law principles-"neutral principles"-it was unwilling to einbrace that approach without limitation. The difficulty lies in understanding the nature of this limitation. First, in what circumstances are documents too ecclesiastical in tone to permit judicial determination of their meaning? For example, was the Georgia court correct in assuming that the meaning of provisions in the Presbyterian Church's "organizational constitutions" could be determined by a court? If the hierarchy liad protested the court's interpretation, could the court have rejected a claim that the document's neaning could be understood only in reference to religious concepts? Did the Court intend to inake the hierarchy's right to control a local church turn on local law rather than on the church's own rules? What local laws would be unconstitutional because they violated free exercise rights or led to entanglement of civil courts in religious affairs? These questions remain unanswered. Moreover, the stability of the Jones approach is undermined by the size of its inajority; four members of the court apparently stand ready to reject it entirely in favor of the strict deference principles espoused in Milivojevich.

The Supreme Court decisions froin Watson to Jones suggest a troubled court unable to find an acceptable framework for analysis of the basic issue: what is the proper rule for civil courts to apply when asked to adjudicate internal church disputes? Part II of this Article critically analyzes the four decisionınaking principles that the Court has suggested: contract, strict deference, the ban on doctrinal decisions, and neutral principles. It rejects strict deference and neutral principles, concludimg that a court should usually apply the contract principle, although it is necessary to limit the judicial role with a carefully articulated ban on doctrinal decisions. Such a ban, however, if properly understood, shonld rarely be relevant.

\section{II \\ ENFORCING CHURCH RULES}

Most of the Supreine Court's church dispute cases have involved the contract function rather than the rulemaking function. That is, they lave involved claims that a party had violated a private, internally generated understanding, rather than claims that state-made rules had been breached. In Watson the plaintiffs contended that their closen 
elders, and not those currently in possession of the church building, were the proper officers under church rules. In Gonzalez the question was whether the terms of a will bound the church to appoint as chaplain the ten-year-old descendant of the testator. In Kedroff and Kreshik the dispute was over the authenticity of the incumbent Moscow patriarch, who was arguably without authority over the American church under the terms of a prior patriarch's edict. In Milivojevich the question was whether the hierarchy's acts exceeded the scope of their authority under both the agreement of affiliation with the American church and the church rules concerning the procedures for defrockment. And in Jones the question was whether church rules permitted the majority of the congregation to withdraw the affiliation with the central church while retaining ownership over the local church property.

Two cases have involved the ruleinaking function. In Kedroff, the court had the side problein of the special state rule created for the occasion by the New York legislature. The rulemaking function was also involved in Hull, where a state law gave the central church control over the local congregation's property, so long as the central church adhered to fundamental tenets of the faith. The issues raised by cases involving the rulemaking function will be considered in Part III.

Part II focuses on the contract function, analyzing how courts should deal with disputes over construction and enforceinent of a church's internal rules or private agreeinents. ${ }^{75}$ Section A of Part II discusses the advantages of the contract primciple as compared to the strict deference primciple endorsed by Milivojevich and the Jones minority, or the neutral primciples approach approved by the Jones majority. It is argued that courts asked to perform the contract function should decide internal church disputes by applying the contract primciple as they would with any other nonprofit association. Section B evaluates the difficulties that might be encountered in following the contract primciple. It concludes that a inodest version of the ban on doctrimal decisions should be the contract primciple's only limitation, and that, properly understood, it is a limit that will rarely apply.

75. I use the phrase "church contracts" or "church rules" in a very broad sense, intending to encompass official organizational documents, such as constitutions, bylaws or articles; informally adopted rules, such as "implied bylaws" to the extent they would be honored in secular organizations; contracts, whether oral or written, express or implied; and terms of trusts, whether implied or express. 


\section{A. Why Courts Ought to Employ the Contract Principle and Enforce Church Rules}

Apart from a few sentences in Jones $v$. Wolf, ${ }^{76}$ the Supreme Court has never considered the advantages that might result from enforcing agreements within religious organizations. Perhaps the point is too obvious to require extended discussion; after all, we normally do enforce private contractual arrangements, and the belief that such enforcement is appropriate and necessary is rather basic to common law jurisprudence. Nor is any different rule usually employed by courts reviewing disputes in nonprofit corporations. Contests over the voting rights of inembers, ${ }^{77}$ the terms of a trust under which assets are held, ${ }^{78}$ the relative authority of various governing bodies within an organization, ${ }^{79}$ and the rights of local constituent organizations vis-a-vis the central authority ${ }^{80}$ are ordinarily resolved by judicial construction and application of the organization's own internal rules and agreements. Before we adopt a different rule for religious associations, such as strict deference, we should consider whether there are important advantages we thereby forego.

There are four main reasons for enforcing internal church agreements: 1) consistency with inost people's expectations and sense of justice, 2) protection of the rehgious freedoin of meinbers, 3 ) the need for enforceable agreements to facilitate the creation of complex organizations, and 4) the absence of satisfactory alternative decisionmaking principles.

\section{Consistency with Our Sense of Justice}

One rationale for the contract principle is that it is consistent with inost people's sense of justice. That is an important reason for enforcing promises, and not just fornal promises made in writing by instruinents explicitly calling for their strict enforceinent. ${ }^{81}$ If the law singles

76. 443 U.S. at $603-04$.

77. See In re Mount Sinai Hospital, 250 N.Y. 103, 164 N.E. 871 (1928).

78. See Holt v. College of Osteopathic Physicians and Surgeons, 61 Cal. 2d 750, 394 P.2d 932, 40 Cal. Rptr. 244 (1964); Queen of Angels Hospitals v. Younger, 66 Cal. App. 3d 359, 136 Cal. Rptr. 36 (2d Dist. 1977).

79. See American Center for Educ., Inc. v. Cavnar, 26 Cal. App. 3d 26, 102 Cal. Rptr. 575 (2d Dist. 1972) (powers of the executive committee).

80. See Colorado Labor Council, AFL-CIO v. AFL-CIO, 349 F. Supp. 37 (D. Colo. 1972), vacated on other grounds, 481 F.2d 396 (10th Cir. 1973); California Dental Assoc. v. American Dental Assoc., 23 Cal. 3d 346, 590 P.2d 401, 152 Cal. Rptr. 546 (1979).

81. Enforceable agreements may of course be oral, as well as written, and they may be implied from the conduct of the parties rather than from any express words of promise, written or oral. E.g. , Grant v. Long, 33 Cal. App. 2d 725, 92 P.2d 940 (4th Dist. 1939); Shepard v. Glick, 404 S.W.2d 441 (Mo. App. 1966); Restatement (SeCOND) of Contracts, \& 21 (Tent. Draft No. 7, 1973). Indeed, promises may even be enforced when they are not part of any agreement, written, 
out the breach of church agreements as peculiarly beyond judicial remedy, it nay heighten the sense of injustice that broken promises can produce.

Significant property interests are often at stake in church disputes. A breach can mean inaterial loss just as surely as a violated business understanding. Where individuals or entire congregations have put money and effort toward creating a church building, they suffer a tangible loss if a central hierarchy unjustifiably assumes control over it. In church disputes, there are often imtangible losses as well. The faithful might beheve that traitors or heretics have grasped control of the church, and, as in all family fights, great emotional strife and bitterness may result. If one reason courts enforce agreeinents is to provide a peaceful mechanism by which a culturally shared sense of justice nnay be vindicated, it surely makes little sense to exempt from the process those very battles that arouse the greatest passions.

\section{Protecting the Religious Freedom of Church Members}

Ensuring religious societies' autonomy from governmental imtervention certainly seems like an appropriate goal, consistent with the philosophy of the religion clauses of the first amendinent. The strict deference principle achieves this goal by msulating the decisions of hierarchical authorities from review by civil courts. One cost of this insulation is the impairment of the religious freedom of members of the local church who claim that an action by the hierarchy violated church rules, because that claim will be ignored regardless of its merits. Strict deference is oblivious to the tension between ensuring total autonomy to rehigious societies, its apparent goal, and affording members of those societies the legal remedies nonnally available to attack unauthorized "inanagement" actions. ${ }^{82}$ In its concern for the religious freedom of the central organization, it ignores the claims of religious freedom by

oral or imphed, when they reasonably induce rehance by the promisee. Id. at $\$ 90$. In all such cases, there seem to be shared cultural values calling for enforceinent of promises; a broken word is a wrong which justifies a remedy. P. AtTyah, AN InTroduction to the Law of Contract 1-2 (2d ed. 1971); Cohen, The Basis of Contract, 46 HARv. L. Rev. 553, 571 (1932); Gardner, $A n$ Inquiry into the Principles of the Law of Contracts, 46 HARv. L. REv. 1, 20 (1932).

Of course, not every broken promise is actionable. There are limits meant to ensure, for example, that the law does not involve itself in enforcing words of promise contained in gratuitous pleasantries. See, e.g., Kirksey v. Kirksey, 8 Ala. 131 (1845); Stelmack v. Glen Alden Coal Co., 14 A.2d 127, 339 Pa. 410 (1940); Restatement (Second) of Contracts $\$ 24$, Comment b (Tent. Draft No. 7, 1973). But I offer no argument here that the law ought to enforce internal church agreenents in circumstances in which it would not otherwise act; whatever jurisprudential principles support those exemptions from the general rule can apply equally to the understandings forned within church societies.

82. Laurence Tribe has also made this observation. L. TRIBE, supra note 12, at 881-85. 
constituent or affiliated organizations as well as the individual members.

Indeed, it is hard to see how the central orgamization could have any mdependently derived rights. The organizational entity deserves constitutional protection because it is an imstrument of the faithful in advancing their religious beliefs; it therefore should have no constitutionally based insulation from the claims of its members. The constitutionally required deference to the decisions of church hierarchies should extend only so far as the authority granted them or agreed to by the cliurch members.

The contract principle, unlike strict deference, ensures members' rehigious freedom by implementing the parties' intentions. For example, many hierarchical churclies are organized witl absolute power in a leader, or in a select group of high cliurch officials. If that is the arrangement, then disgruntled members should have hittle recourse to the courts. A court could not, consistently with a genume principle of nonintervention, ignore the agreement and substitute its judgment for that of the ecclesiastical authority. To do so would deny the cliurch members the religious authority that they have chosen. But thus understood, the insulation of churcli tribunals from substantive review of their decisions is grounded upon the religious freedoms of the church members who created or agreed to the authority of those tribunals. The court should not, by way of adjudicating church disputes, alter the church's governing structure, imposing one polity on a church that has chosen another. Similarly, a court should not impose a hierarchy on members who liave cloosen a democratic structure. If the Constitution bars the governinent, through its courts, from imposing a democratic polity upon a churcli that prefers an absolute hierarchy, then surely it also bars the courts from imposing an absolute hierarchy upon a church that has cloosen to give its ruling autlorities more limited power.

The advantage of the contract principle, then, is that it takes the intentions of the parties as its guide. Rather than applying a previously fixed notion of low to balance the claims of the organizational authorities against the claims of its members or constituent bodies, it accepts the solution cliosen by the churcl itself. The point seems alınost too obvious to require statement; it is after all the familiar and fundamental principle of contract. But in adjudicating church disputes, it may also be the only constitutional solution, for it is the only solution that does not require the governinent to impose its notions of ecclesiastical polity on a cluurclı's warring factions. 


\section{Enforcement as an Organizational Aid}

-Another reason we enforce contracts is to facilitate the creation of the complex relationships required by modern society. A law of contract is necessary if people are to form partnerships, associations, and corporations. The same principle applies to the formation of religious societies. By denying enforcement of their agreements we deprive churches of a major aid to formal organization.

Consider, for example, the position of the American brancli of the Serbian churcli at the time it was considering whether to affiliate with the imternational church and its Yugoslavian hierarchy. Assume that, as claimed, the American church desired to affiliate only if it obtained assurances of contmued independence as to certain specified matters, and that the Yugoslavian hierarcliy was willing to enter such an agreement. If we abandon the contract principle, low could the parties liave effected their deal? Under the strict deference principle embraced in Milivojevich there is no document they could have prepared which would have bound the hierarchy to such limits on its power in a nanner enforceable in the American courts. The strict deference primciple therefore disables the central Serbian churcli and its American supporters froin achieving the affiliation they desire.

In order to induce someone to trade something now in return for a promise of future perfornance, that promise inust be enforceable. The need for enforcement is a fundamental rationale for contract law; denying it burdens potential promisors as mucli as past promisees. If the law makes promises within religious groups unenforceable, some will be unwilling to rely on such promises, just as people inay be unwilling to lend money to minors, who are legally incapable of entering binding contracts. If religious societies cannot fashion their own governing arrangements, their organizational efforts will be burdened. The practical impact of that burden inay or may not be great, but still the rule is unacceptable; it simgles out religiously inspired efforts for special limits on contractual freedom. Such discrimination seems difficult to justify or sustam constitutionally. ${ }^{83}$

\section{The Absence of Satisfactory Alternatives}

The contract principle, in contrast to strict deference, is compatible with prevailing notions of justice, resolves the tension between organizational autonomy and inembers' rights, and ensures religious societies the same opportunity to further their associational goals as is enjoyed

83. Cf. McDaniel v. Paty, 435 U.S. 618, 638 (1978); Walz v. Tax Comm'n, 397 U.S. 664, 674 (1970); Fowler v. Rhode lsland, 345 U.S 67, 69 (1953); Pierce v. Society of Sisters, 268 U.S. 510 (1925) as characterized in Evans v. Newton, 382 U.S. 296, 300 (1966). 
by secular organizations. This section examines some difficulties inherent in the two alternative rules considered by the Court: strict deference and neutral principles.

\section{a. Strict Deference}

i. The failure to explain the different treatment of hierarchical churches. One glaring deficiency in the strict deference principle is its failure to explam why hierarchical churches are treated differently, for constitutional purposes, from congregational churches. The nonintervention logic of Milivojevich applies equally, if at all, to both kinds of churclies.

Milivojevich, and the portion of Watson upon which it relies, bar courts froin determining the extent of hierarchical authority permitted by clrurch rules. Consequently, a court inust always uphold the decision of the hierarcliy against claims that it exceeded its jurisdiction or did not follow cliurch rules. In Milivojevich, for example, the Court said Illinois' imstake was not in misreading church docuinents, but in assuming that it could review the church constitution to decide jurisdictional questions. ${ }^{84}$ Matters of governance in hierarchical churches, Milivojevich concludes, are ecclesiastical in nature and not to be examined by courts.

The decisions of congregational churches against analogous claims can be reviewed, lowever. Why inatters of governance are ecclesiastical in hierarchical churches but not in congregational churches remains unexplaimed. It would doubtless puzzle adherents of those congregational Protestant denominations that see their governance arrangeinents as a theologically critical distimction separating thein from churches adopting less democratic structures.

ii. The difficulty in identifying which churches are hierarchical. Since Watson, affixing the proper label-hierarchical or congregational-to a churcli organization has held considerable legal importance. Which label apphes, however, is not always clear. The Supreme Court has given little guidance. Justice White, a consistent advocate of the strict deference principle for hierarchical churches, inentions the issue in his brief Milivojevich concurrence, but says merely that a court nay use its judgment to determine the appropriate label. ${ }^{85}$ The problein has been addressed by lower courts, but they have not always

84. See text accompanying notes 60-61 supra.

85. 426 U.S. at 725. Paul Kauper has also observed that courts will not always find it easy to make the categorization, although he does not suggest that there is anything defective about the basic approach. He appears to treat it more as a problem of proof than a problem of principle. Kauper, supra note 19, at 90-91. 
agreed on whether a particular denomination is in fact hierarchical. ${ }^{86}$

It is hard to imagine what guidance the Supreme Court could have given. A wide range of governing arrangeinents is possible, and it is not always self-evident which is hierarchical and which congregational. For example, is a church with a central authority elected by democratically chosen representatives hierarchical, thus triggering strict deference where one faction claims that the elections have been administered in violation of church rules? Would an unaffiliated congregation, a storefront church, in which the minister has traditionally ruled autocratically be hierarchical or congregational? Is the only difference between this "hierarch" and the Pope the size of their einpires?

Even churches that clearly have centralized ecclesiastical authorities do not all possess the same power over their local affiliates. Some may choose the local clergymen; others may merely certify quahified persons from whom the local congregation may choose. Churches also vary im the amount of discretion they give their local affiliates im choice of doctrine, financial management, and involveinent of lay people in church governance. Which combination of traits is necessary for a church to be labeled hierarchical?

The entire process of labeling seems inherently arbitrary. Presunably when there are enough limits placed on a central church authority, it ceases to be hierarchical and the court will entertain claims that the limits have been exceeded. But as the number of limits decline, at some point the label "hierarchical" will attach, and a court, employing the strict deference principle, will not entertain claims that there has been a violation. In order to complete this inquiry and choose the proper label, the court will have to review church rules and organizational documents; yet if it concludes from that review that the church is hierarchical, it must ignore the limits on hierarchical authority that it has discovered in the process. It is indeed difficult to offer a principle that justifies this process, much less one to guide its execution. The contract principle avoids this entire inquiry by not attempting to force all church organizations into one of two boxes; it accepts the variations in governance structure that exist, and directs the court to adjudicate the dispute in accord with the choice made by the church before it.

\section{b. Neutral Principles}

The notion of decision by "neutral principles" was first mentioned by the Supreme Court in Hull and more fully defined in Jones $v$. Wolf. Where neutral principles permit enforcement of church rules on the same basis as the rules of any secular association, they do not differ

86. See note 19 supra. 
from the contract principle. Some of Jones' limits on imdependent judicial consideration of church rules do conflict with the contract principle, however. Those limits are an effort to keep courts from decidimg questions of religious doctrine, but have resulted mostly in confusion. The concern about doctrinal decisions is important, however, and a solution consistent with the contract principle is suggested in Section B.

The dispute before the Court in Jones $v$. Wolf was a typical church dispute: a local congregation, dissatisfied with the central church, decided to withdraw. Also typical was the division in the local congregation on this question; there was a minority faction whicl desired to maintam affiliation witl the central church. The Court confronted two issues. First, did the local church property belong to the local congregation, or to the central church? Second, if one concludes that ownership is in the local congregation, which faction speaks for that congregation and exercises control over its property?

The contract principle would decide each of these questions in the same manner as for a secular organization. Ownership of property might be determined by examination of the deeds, but the inquiry would not necessarily stop here. Competing claimants for property may have contractual arrangements between them that are not reflected in the deeds, and even though unrecorded, sucl agreeinents bind them. Nor is formal contract the only method by which such an agreement may be established; other sources may establish intentions in a manner adequate to make them legally bindimg. In secular fraternal organizations, for example, similar disputes arise between local affiliates and the national organizations. The national organization may prevail by showing that internal organizational rules, accepted by the local upon its affiliation, provide that the local's property is transferred to the national organization upon loss of the local's charter of affiliation. ${ }^{87} \mathrm{~A}$ similar examination of internal organizational rules would also ordinarily decide who has authority to speak for the local affiliate if it is divided. In the absence of established rules, majority will prevails. ${ }^{88}$

How then does adjudication by "neutral principles" differ from the contract approach? There are a number of possibilities reflected both in Jones and in the lower court cases.

87. E.g., CAL. CorP. CODE $\S 7132$ (a)(5) (West Supp. 1980).

88. Francis v. Perry, 82 Misc. 271, 144 N.Y.S. 167 (1913); Johnson v. South Blue Hill Cemetery Assoc., 221 A.2d 280 (Me. 1966). A good example of a church dispute, somewhat similar to Jones, resolved along contract principles, is Hayman v. St. Martin's Evangelical Lutheran Church, $227 \mathrm{Md}$. 338, 176 A.2d 772 (1962). When the majority faction of a local congregation voted to withdraw from the parent church, the minority brought an action. The court examined the relevant governing documents and concluded that this particular congregation benefitted from a "grandfathering" provision allowing it to retain its property and withdraw so long as it did so by the two-thirds vote required in its own bylaws. 
i. The formal title doctrine. Some lower courts have employed a variant of "neutral principles" that they call the formal title doctrime, under which they look at the language of the deeds in question, and award the property accordingly with no further inquiry. ${ }^{89}$ It is the apparent assumption of these cases that there is some difference of constitutional significance between a court's examination of deed language and its examination of internal organizational documents, such that the former is permitted but the latter is not. This approach places a premium on placing the parties' intention in the correct piece of paper, and seems to have little to cominend it.

ii. Deference to the hierarchy's definition of religious terms. Jones suggests that title can be ascertained by looking at all of the documents, not just the deed language, but with one limitation: to the extent that understanding those documents requires understanding of religious terins, the court must defer to the view of the "authoritative ecclesiastical body," ordinarily the hierarchy. ${ }^{90}$ Whether this limitation proves to be a problem depends on how the court applies it. Almost any terms in the organizational documents of a church can be characterized as religious, and a broad application of this limitation could therefore give the court the saine meaningless role it has under the strict deference principle. This result may be especially likely if the court is required to accept the hierarchy's assertion that particular terms or documents have religious significance that only they can authoritatively construe. Jones does not say whether courts are required to accept such an assertion, nor does it offer guidance on how to determine whether a terin is sufficiently secular to permit judicial construction and application. Jones' limitations are efforts to prohibit courts froun deciding doctrinal issues, but they are too confused conceptually to provide much help on this serious point.

iii. Determination of which faction speaks for the congregation. Finally, Jones addresses the problem of deciding which faction of the local congregation represents it, and it proposes an approach quite different from contract. There are two inain differences. First, Jones holds that to the extent one relies on church rules to identify which

89. Justice Brennan's concurring opinion in Maryland \& Virginia Eldership of the Churches of God v. Church of God at Sharpsburg, Inc., 396 U.S. 367, 370 (1970), appears to approve such cases. One court has pointed out that courts which opt for the formal title doctrine invariably conclude that ownership hes in the local congregation, since the deeds usually so specify, while courts which opt for a deference approach invariably find for the central church authority. Paradise Hills Church, Inc. v. International Church of the Four Square Gospel, 467 F. Supp. 357, 36061 (D. Ariz. 1979).

90. 443 U.S. 595, 604 (1979). 
faction speaks for the local congregation, the court must defer to the hierarchy's determination. This is a complete throwback to the strict deference principle; it gives one of the claimants to the property, the hierarchy, complete power to decide whether the other claimant, the dissident local faction, has standing to make the claim. In the case of the secular association, the court itself would examine internal rules to decide whether the dissident faction properly represented the local organization. There is no reason, if one rejects strict deference generally, to take a different approach here. ${ }^{91}$

The second difference between the contract principle and the Jones approach is even more surprising: it is the suggestion that state law may declare church rules irrelevant to the determination of which faction properly represents the local congregation. Of course, corporation codes and case law often place limits on particular governing arrangements that private groups may adopt, but there is probably no precedent for a law that entirely replaces them with state-created rules. It seems particularly surprising to take this course with churches, for which we are especially concerned to avoid unnecessary governmental intrusion. One must question whether the court really intended this result; it is, after all, dicta, and may not have received adequate attention. ${ }^{92}$

This analysis suggests that to the extent the neutral principles approach is different from our contract principle, it has hittle to commend it. Neutral principles does, however, recognize the problem of doctrinal pronouncements, which an unaided contract principle ignores.

\section{B. Remaining Problems with the Contract Principle}

The contract principle offers a number of advantages over alternative principles, but it also has its problems. Two arguments that are sometimes made against the contract principle cannot withstand careful analysis. Two other arguments are more substantial, but involve problems that can be solved by the courts.

\section{Two False Problems \\ a. The "Hands-Off" Argument}

One objection to examining church rules is that any judicial involvement im reviewing the decisions of hierarchical authorities constitutes improper and unconstitutional governunental imtrusion into

91. One possible exception is the concern with doctrinal pronouncements. That problem is addressed in Part II, Section B.

92. If such a mle were in fact intended, it would be an externally generated rule, and its suitability could be analyzed by the approach suggested in Part III. 
church affairs. ${ }^{93}$ Under this view, the very process of judicial scrutiny constitutes unconstitutional intrusion. The hierarchy should not have to persuade a civil judge that its actions were within the scope of its mandate. This argument is certainly not frivolous. It is troublesome to have a secular court instruct a religious leader on the nature of his authority. The problem is generating a judicial response that does not involve even more objectionable intrusion.

If the goal is avoidance of judicial involvement in church disputes, it is not achieved by deference to the view of the hierarchy. Deference is also intervention, smce it inserts the authority of the state imto an internal church dispute in support of one faction. The court may avoid hearing the parties' evidence, but that hardly means that there is no intrusion. Any time the court directs that a battle between two groups be resolved in a particular way, it has intruded, whether the order is based on deference to a private authority or on the court's independent judginent. If reviewing the evidence constitutes too much interference, it is hardly satisfactory to have the court decide the case without considering the evidence. Yet that is exactly the solution offered by the strict deference alternative, as well as by portions of Jones.

A true "hands-off" approach would have the court refuse to entertaim the case at all, leaving the parties where the court found them. This seems like the only possible result where the court may not hear the evidence that is critical to deciding the case. The court would in effect find for the defendant, regardless of which faction happens to be in that role. This approach is really the only one that satisfies a noinvolvement principle, but it has other costs. It would forego all of the advantages offered by the contract principle: consistency witl our sense of justice, protection of church members' religious freedom, and facilitation of organizational efforts. A hands-off approach also bars relief for even the most flagrant abuses. Our system presumes that judicial decisions will yield fairer results than leaving the disputing parties to fight out their battles alone. ${ }^{94}$ There is no reason to alter that

93. Why this argument should apply only to hierarchical authorities, and not, for example, to the elected officials of congregational churches, is difficult to explam.

94. The modern concern for avoiding intrusion into church affairs has not always been present. From the late nineteenth century through the first two decades of the twentieth century, soine state courts involved themselves in an aggressive campaign of intervention against the authority of the Roman Cathohic hierarchy, relying on statutes which required that all church property be held by corporations controlled by laymen. The coinplete story is told by Kauper \& Ellis, Religious Corporations and the Law, 71 MiCH. L. REv. 1500, 1520-27 (1973). In soine cases these lay boards used their power over church property as a tool with which to challenge the ecclesiastical authority of the local hierarchy. In Pennsylvamia this trend climaxed in a series of five Pennsylvama Supreme Court decisions, all of which went against the church authorities. Novicky v. Krauczunas, 245 Pa. 86, 91 A. 657 (1914); Novickas v. Krauczunas, 240 Pa. 248, 87 A. 686 (1913); Mazaika v. Krauczunas, $233 \mathrm{~Pa}$. 138, 81 A. 938 (1911); Mazaika v. Krauczunas, 229 Pa. 47, 77 A. 
assumption im the case of church disputes. There may be a small group of cases, discussed later in this section, where the difficulties of adjudication are so intractable that no other solution seems possible. But the cost of abstention argues that it should not be a routine response.

\section{b. The "Dismal Swamp" Rationale}

Zechariah Chafee, Jr. once suggested that judicial reluctance to become involved in church disputes might be explaimed by a "dismal swamp" policy, ${ }^{95}$ and there is some evidence of this view in the opinions. ${ }^{96}$ Chafee's dismal swamp describes the internal affairs of any organization that conducts itself by rules or rituals at once intricate and unfamiliar. A court unacquainted with Eastern Orthodox religions may become uneasy when asked to determine the procedural regularity of a "sobor" or the validity of the method by which the "metropohtan" was chosen. Resort to organizational documents may heighten a court's feeling of incompetence, particularly if, as is likely, neither their vocabulary nor their logic seem to relate comfortably to accepted legal principles. These problems of adjudication are more likely to arise with review of decisions in hierarchical than in congregational churches, since the congregational polity ordinarily adopts the familiar secular concept of inajority rule as its core governing principle. ${ }^{97}$

This dismal swamp problem is not peculiar to church disputes,

1102 (1910); Krauczunas v. Hoban, $221 \mathrm{~Pa} .213,70$ A. 740 (1908). The situation was not remedied until 1937, when hierarchical control over local church property finally became possible. See Canovaro v. Brothers of the Order of Hermits of St. Augustine, 326 Pa. 76, 191 A. 140 (1937). But that experience still had echoes much later in the twentieth century. See Northside Bible Church v. Goodson, 387 F.2d 534 (5th Cir. 1967), in which the court struck down an Alabama statute authorizing a local congregation to sever its connection with a parent church while retaining possession of the property, whenever that course was favored by $65 \%$ of the members. In the case in question, apphication of this rule would have undermined the hierarchical structure of the Methodist Church. It would be understandable if judges attempting to avoid this questionable course chose to defer to the hierarchical authorities. Yet, if the court is to render any decision in internal church disputes, it cannot avoid some amount of intrusion. Certainly, sustaining the hierarchy automatically, without regard to church rules, is no better than undermining the authority it has under those rules. And neither approach offcrs much advantage over a good faith attempt to apply the rules. Applying church rules also involves intrusion, but it seems like the least objectionable kind. Although the Pennsylvania cxperience suggests that courts will not always be evenhanded, that is hardly a surprise. Nonetheless, their adjudications seein inore likely to produce fair results than private adjudications by one of the parties, which is the effect of strict defercnce.

95. Chafee, The Internal Affairs of Associations Not-for-Profit, 43 HARv. L. REv. 993, 1021 (1930).

96. Both Watson v. Jones, 80 U.S. (13 Wall.) 679, 729 (1872), and Serbian E. Orthodox Diocese v. Milivojevich, 426 U.S. 696, $714 \mathrm{n} .8$ (1975), mention the civil courts' ignorance of religious doctrime as a basis upon which to decline decision.

97. See Stansberry v. McCarty, 238 Ind. 338, 149 N.E.2d 683 (1958); Atkins v. Walker, 284 N.C. 306, 200 S.E.2d 641 (1973); Graham v. Lockhart, 42 N.C. App. 377, 256 S.E.2d 518 (1979); Mangum v. Swearimgen, S65 S.W.2d 957 (Tex. Civ. App. 1978); Annot., 15 A.L.R.3d 297, 302 (1967). 
however, since courts often face similar problems in other areas. Not surprisingly, the most ready analog to the mysteries of religion is the mysteries of science, and court observers liave becoine accustoned to the complaints of trial courts attempting to unravel complex patent cases, ${ }^{98}$ or appellate courts asked to review the technical decisions of administrative agencies. ${ }^{99}$ Indeed, those problems may be even more troublesome than a cliurch dispute, because the court nay be asked to adjudicate substantive issues on technical questions, rather than merely to trace the lines of authority to test whether a challenged rule was within the decisionmaker's jurisdiction. In the science area there have also been proposals to limit the ambit of judicial authority, but they have not prevailed. ${ }^{100}$ Courts do the job reluctantly, but they do it because there is no alternative that can afford the same protections to the parties. The same is true in churcli disputes: only the court can enforce the internal agreement, and we place all parties at a severe disadvantage when we decline to become involved.

Perhaps there is greater reason for caution in cliurcl cases, lowever, for mistakes of adjudication may raise constitutional concerns. A civil court might misconstrue clurch rules and erroneously sustain, or reverse, the decision of a church authority. But the alternatives may be no better. Indeed, the harm from occasional factfinding errors may be less than the harm from always deferring to the views of the hierarchy, the only apparent alternative solution. Strict deference will produce error in some proportion of cases, in that it will sometimes sustain and enforce a view that is in fact different from that which the parties agreed upon-tliat is, it will sustain an erroneous interpretation of the internal agreement. What is worse, the strict deference rule uniformly favors one class of parties, the hierarcliy, over its cliallengers, so that errors will consistently favor one side. In the context of church disputes, such an approacli is, in effect, a governmental policy designed to favor one form of cliurcl polity-absolute hierarcliy. This raises greater constitutional problems than the occasional errors, randomly distributed among parties, that may result from an erroneous factual determination made by a neutral forum.

98. See Blonder-Tongue Laboratories v. University of Ill. Foundation, 402 U.S. 313, 331 (1971); Marovitz, Patent Cases in the District Courts-Who Should Hear Them?, 51 IND. L.J. 374 (1976).

99. See Bazelon, Coping with Technology Through the Legal Process, 62 CoRnell L. Rev. 817 (1977); Leventhal, Environmental Decisionmaking and the Role of the Courts, 122 U. PA. L. Rev. 509 (1974).

100. Talbott, "Science Court": A Possible Way to Obtain Scientific Certainty Based on Scientific "Fact"?, 8 ENvT'L. L. 827 (1978); Wright, A View on Patent Litigation and on the Patent System, 59 J. PAT. OFF. Soc'Y 409 (1977). 


\section{Two Real Problems \\ a. Doctrinal Decisions}

Since Watson the Supreme Court has repeatedly indicated that courts may not decide questions of church doctrine. The Court relied upon the ban on doctrinal decisions in Hull, in which it found that Georgia could not make the outcome of a church property dispute turn on a civil court's determination of whether the central Prcsbyterian church had departed from basic tenets of the faith. ${ }^{101}$ The problem was addressed again in Jones $v$. Wolf, in which the Court indicated that in construing church documents under a neutral-principles approach, a court must defer to church hierarchies as to the meaning of any religious terms, on the assumption that a court cannot make theological decisions. ${ }^{102}$ Since almost any term in a church docuunent could be characterized as religious and thus involve a theological decision, a broad application of the ban on doctrimal decisions could eliminate any use of the contract primciple-courts would decide no cases involving religious concepts. Few cases, however, present the problem of governmental determination of religious doctrime, a role that the first amendment almost surely denies to any secular officials. More common are a second group of cases in which the court is asked to determine which religious doctrime the embattled parties agreed to follow. This kind of question is very different and need not present the first amendment difficulties inherent in the first group of cases.

The best illustrations of the first kind of case are not church disputes at all, but rather the practices struck down in the Court's wellknown school prayer decisions. ${ }^{103}$ In those cases, the government had put its official blessing upon particular religious views when it composed prayers or selected biblical passages for recitation in official religious exercises. Within the church dispute context, Hull itself is the best example of this problem. ${ }^{104}$ The state law at issue in Hull specified that the hierarchy's claim to the property of the local congregation was conditioned upon its adherence to the basic tenets of the faith, as they prevailed at the time of the local congregation's affiliation. It was Georgia law, and not church rules, which made the hierarchy's adlerence to the faith relevant, and there were no guideposts for ascertaining the "true faith" except those provided by the secular law under which

101. See text accompanying notes 52-55 supra.

102. See text accompanying notes 62-74 supra.

103. School Dist. v. Schempp, 374 U.S. 203 (1963) (Bible readings); Engel v. Vitale, 370 U.S. 421 (1962) (state composed "non-sectarian" prayer).

104. Although unique among the cases considered by the Supreme Court, the practice struck down in Hull had a long history and had been followed by many other courts. Sce the discussion in Kauper, supra note 19. 
the claim was made. Thus, Georgia law was set up as the ultimate authority against which the hierarchy's faithfulness to true Presbyterianism was tested. These facts, as inuch as those in the school prayer cases, illustrate impermissible governmental determination of "proper" religious doctrine. Hull was a peculiarly appropriate case for apphication of the ban on doctrinal decisions-peculiarly appropriate, because its critical facts were so different from those presented in the remaining church dispute cases the Court has considered.

Milivojevich ${ }^{105}$ exemplifies this second kind of case. In Milivojevich the Court had to decide whether the central hierarchy had acted within the scope of its authority when it defrocked the American bishop and divided the American diocese into three separate districts. Either question could be characterized as doctrinal, as indeed could any decision involving church governance. But the Illinois Supreine Court, in the decision that the United States Supreme Court ultimately reversed, did not purport to decide how a proper Serbian Orthodox church ought to be governed; it inerely determined, by examination of church documents, how the relevant parties had decided to govern this particular church. ${ }^{106}$ In performing this task, a court is not settling a doctrinal dispute by announcing the "true faith"; it is merely construing a contract. For first amendment purposes, tlis ought to be a critical distinction.

The need for this distinction between deciding the "true faith" and interpreting the intentions of the parties is illustrated by a pair of state court cases involving Jewish synagogues. ${ }^{107}$ Both synagogues held their property under trust instruments limiting use of the building to Orthodox Jewish services. In one case the instrnment even specified Orthodox services as traditionally conducted in Poland. ${ }^{108}$ In each case the majority of the congregation voted to allow the inen and wornen to sit together during services, and the minority faction then brought suit, arguing that the Orthodox principles required by the trust barred mixed seating. In one case the court sustained the arguinent and enforced the trust; ${ }^{109}$ in the other it found that Orthodox principles did not necessarily bar mixed seating and therefore declined to upset the congregation's action. ${ }^{110}$

A court can construe and apply the terins of agreements, such as

105. See text accompanying notes 57-61 supra.

106. Id.

107. Katz v. Singerman, 241 La. 103, 127 So. $2 \mathrm{~d}$ 515, appeal dismissed and cert. denied, 368

U.S. 15 (1961); Davis v. Scher, 356 Mich. 291, 97 N.W.2d 137 (1959).

108. Katz v. Singerman, 241 La. at 107,127 So. $2 d$ at 517.

109. Davis v. Scher, 356 Mich. 291, 97 N.W.2d 137 (1959).

110. Katz v. Singerman, 241 La. 103, 127 So. 2d 515, appeal dismissed and cert. denied, 368 U.S. 15 (1961). 
the synagogue trust instruments, without impermissibly identifying the "true faith." What the courts needed to decide in the synagogue cases was not the essence of Judaisin, an unconstitutional if not impossible task, but rather the essence of the grantor's intent. The courts ought to have determined whether the language of the trust instrument by which the grantor conditioned his gift should have been construed, under norinal rules of interpretation, to bar mixed seating. It is important that the courts decide such cases, if possible, so that potential benefactors can be assured that their contributions will be used as they intended. The contract principle protects this interest without abandoning the important principle of Hull barring governmental determinations of religious doctrine. ${ }^{111}$

Interpretations of intent may be easy or difficult depending upon the facts of the case. For example, the trust instrument requiring Orthodox Jewish services could surely be the basis of a court order barring the serving of pork during prayer, regardless of the desires of the congregation. The question of mixed seating may be more difficult if, as the cases suggest, it is an issue as to which rabbimical authorities nay differ. The court's task, however, is not to decide which of the conflicting rabbinical authorities has the true understanding of Orthodox Judaism, but to decide what restrictions the grantor intended to impose when he used that terin. As in other cases of trust or contract imterpretation, expert testimony may be relevant to establish a "usage of the trade," so to speak.

Trade usage testimony was admitted, for example, to decide the case of Rabbi Fisher. Congregation B'nai Yitzhok sought his services as a cantor to sing the chants that are part of the traditional Jewish High Holiday services. Rabbi Fisher agreed, for a fee of $\$ 1200$, after being assured by the congregation's regular rabbi that traditional Orthodox principles, including separation of sexes, would be observed at the services. On the eve of the performance, the congregation voted to have mixed seating, and Rabbi Fisher felt that he therefore could not attend. He was unable on such short notice to find alternative employment at the same fee, and he brought a contract action for the difference. The question was whether the congregation had breached the agreement by adopting mixed seating, although there was nothing in the written contract on this point. The court held for Rabbi Fisher,

111. If we adopted a different view, we would effectively bar the creation of enforceable trusts for religious uses. Surely a grantor ought to be able to specify that his gift be used only for Orthodox Jewish services and expect to be able to enforce that condition even if a majority of the congregation succumb to the clarms of Jews for Jesus. If we are unable to assure potential donors that such restrictions are enforceable, we may well reduce the ability of religious organizations to attract contributions. The donative impulse may be dampened if potential benefactors are told that it is not possible to assure them that their contribution will be used only for their faith. 
relying on the principle that "when a custom or usage is once established, in absence of express provision to the contrary it is considered a part of a contract and binding on the parties though not mentioned therem." "12 The ban on mixed seating, as an establislied custom of Orthodox synagogues (although apparently a disappearing one), was thus read into the contract on ordimary commercial law principles. The court's decision did not establish rehgion or endanger its free exercise. As in the trust cases, it merely employed neutral secular principles to establish the parties' intent.

Although this approach should generally be satisfactory, there are some remaining difficulties. First, it is possible that a trust or contract inay in fact intend terms to have doctrinal ineanings beyond the court's competence to unravel. For example, it is conceivable that in our synagogue cases a grantor might have ineant to limit use of the building to Orthodox Jewish services, however that terin was understood and defined by religious authorities. If religious authorities were then in fact divided over the propriety of a proposed use, there would be no basis upon which a secular court could resolve the dispute. The court could not decide which rabbinical authority held the correct view, just as in Hull it could not decide the basic tenets of Presbyterianism. This would be that rare, intractable case in which a court would be forced to abstain, in effect giving judginent to the defendant.

\section{b. Vagueness: Is There an Enforceable Agreement?}

Deciding church disputes with the contract principle presents another difficulty, more likely to arise than the problem of courts deciding doctrimal questions. It is the problein of vagueness: What does a court do when the intent of the parties, or the intent of the grantor of a cliaritable bequest, cannot be ascertained clearly enough to resolve the present dispute. There are two difficulties likely to occur. First, there nay be a question as to whether the parties entered into an agreement. In unany cases there will be no fornal contract document, and perhaps ordinary principles would be stranied by characterizing the relationship as contractual. Second, a purported agreement inay be too ambiguous or incomplete to permit its enforcement. While there may be no first amendinent difficulty in enforcing an agreement containing religious terms, there may be a practical problem in construing terms with enough certainty to permit resolution of the dispute.

Establishing the existence of an agreement between a local congregation and its central church ordinarily should not be a problem. In

112. Fisher v. Congregation B'nai Yitzhok, 177 Pa. Super. Ct. 359, 364-65, 110 A.2d 881, 883 (1955). 
some cases, of course, there is clearly an agreement, as in Milivojevich ${ }^{113}$ There are also many state court cases involving hierarchy-local disputes in which a written document existed that set forth the terms of relationship, ${ }^{114}$ just as some set of written articles or bylaws ordmarily exists in congregational churches. ${ }^{115}$ But formal evidence of agreement is not always necessary. In the commercial context, courts long ago concluded that parties could bind themselves by a course of conduct evidencing agreement, sometimes substantiated by scraps of writing, sometimes not. ${ }^{116}$ The same can happen with churches, as the state courts themselves have appreciated:

It does not matter whether such agreement to be bound is memorialized. A local church cannot prosper by the benefits afforded by the parent, participate in the functioning of that body, yet successfully disclaim affiliation when a parent acts to the apparent disadvantage of the local, so as to shield from equitable or contractual obligation the valuable property acquired by the locaI clurch either before or during such affiliation. ${ }^{117}$

Needless to say, the same kind of evidence can cut the other way as well, as where the conduct of the parties demonstrates either the absence of an affiliation, or perhaps the mutual termination of a relationship that once existed. ${ }^{118}$

The use of a course of conduct to find an agreement is not limited to ascertaming the relation between imstitutions, such as the local and central churches. Similar primciples can also govern the relationship between the individual and his church, just as they govern the relationship between secular organizations and their members. An individual

113. See text accompanying notes 57-61 supra.

114. E.g., Protestant Episcopal Church v. Graves, 161 N.J. Super. 230, 391 A.2d 563 (Ch. Div. 1978), affd, 167 N.J. Super, 563, 401 A.2d 540 (App. Div. 1979), affd, 83 N.J. 572, 417 A.2d 19, cert. denied, $101 \mathrm{~S}$. Ct. 954 (1980). Of course, the documents may not be complete or clear, and the parties, as in any other contract dispute, inay argue over their significance or ineaning. See, e.g., Paradise Hills Church, Inc. v. International Church of Foursquare Gospel, 467 F. Supp. 357 (D. Ariz. 1979) (plaintiff local church had conveyed title to defendant central church, but then sought reformation on grounds of "inutual mistake"); Brady v. Reiner, 157 W. Va. 10, 198 S.E.2d 812 (1973) (central church rules provide for takeover of local, but question of whether it applies to local church that existed before central church was formed), overruled, Board of Church Extension v. Eads, 230 S.E.2d 911, 918 n.6 (W. Va. 1976).

115. See, eg. , Burnett v. Banks, 130 Cal. App. 2d 631, 279 P.2d 579 (1st Dist. 1955); Henry v. Newman, 351 So. 2d 1277 (La. App. 1977); Nelson v. Ellis, 140 So. 2d 194 (La. App. 1962).

116. See, e.g., U.C.C. $\$ 2-202$.

117. United Methodist Church v. St. Louis Crossing Independent Methodist Cliurch, 150 Ind. App. 574, 589, 276 N.E.2d 916, 925 (1971); accord, Carnes v. Smith, 236 Ga. 30, 222 S.E.2d 322, cert. denied, 429 U.S. 868 (1976); St. John's Hungarian Russian Orthodox Cliurch v. Fedak, 89 N.J. Super. 65, 213 A.2d 651 (1965); Morrow v. Hill, 51 Ohio St. 2d 74, 364 N.E.2d 1156 (1977) ("living relationship" test).

118. See, e.g., Presbytery of Riverside v. Community Church, 89 Cal. App. 3d 910, 152 Cal. Rptr. 854 (4th Dist.), cert. denied, 444 U.S. 974 (1979). 
who participates in a member-owned tennis club ordinarily enjoys a host of governance rights under club bylaws, even though those rights may not have been spelled out in any ineinbership contract between the club and the initiate. ${ }^{119}$ An individual who is a meinber of a proprietary club, operated by a small group of owner-managers, has no such implied rights. ${ }^{120}$ Of course, in either case the relation might be nodified by an express agreeinent, but no express agreeinent is necessary for a court to determine the governance rights of the nneinber, for the court assumes that the parties intended their relation to be governed by the traditional practice of the club. There is a "custom of the trade," so to speak. A court applying the same principles would find that a ineinber of the Roman Catholic Church has no right to appeal a papal decision, at least not in this world, while the nneinber of a congregational churcl with traditions of democratic self-rule is entitled to notice of church ineetings and an opportunity to vote on the hiring of a new pastor. ${ }^{121}$

Concluding that there is an agreement inay not resolve the conflict, however, because the terms of the agreement inay still be vague. Nonprofit corporations often keep records poorly; a current version of the bylaws or the ineinbership rolls often does not exist. Even when reasonably current docunients can be located, and purport to be comprehensive, their language inay be less than precise. This is not surprising, since few such documents will have been drafted with an eye toward creation of an easily enforceable contract.

The church dispute cases provide ready examples of vagueness. In a case like Milivojevich, it unay not be clear from the face of the relevant documents whether the central church was intended to have control over the local congregation's property or its choice of clergyman. ${ }^{122}$ In Kedroff, the American church's claim may have turned on the effect of Tikhon's original ukase, but a court might not be sure how to apply a patriarchal decree granting local autonomy while the hierarchy was "unable to function." 123 And in the synagogue cases, despite careful effort, a court might conclude that a grantor's use of the term "Orthodox Judaism" did not commnnicate a view on the issue of mixed seat-

119. Although the author is not aware of any cases applying this particular principle of nonprofit corporation law in the context of tennis clubs, it has been applied in other membership controlled corporations. See, e.g., Hatch v. Emery, 1 Ariz. App. 142, 400 P.2d 349 (1965).

120. The absence of sucl rights is one of the rationales that may be given in support of the result in Silver Hills Country Club v. Sobieski, 55 Cal. 2d 811, 361 P.2d 906, 13 CaI. Rptr. 186 (1961).

121. Compare Putnam v. Vath, 340 So. 2d 26 (Ala. 1976), with Nelson v. Ellis, 140 So. $2 d 194$ (La. App. 1962), and Randolpli v. Mt. Zion Baptist Church, 139 N.J. Eq. 605, 53 A.2d 206 (1947). But some courts have erroneously viewed such disputes as "ecclesiastical" in nature and therefore beyond their authority to adjudicate. E.g., Henry v. Newman, 351 So. 2d 1277 (La. App. 1977).

122. See text accompanying notes 57-61 supra.

123. See text accompanying notes $39-47$ supra. 
ing. ${ }^{124}$

Vagueness, however, is not a problein peculiar to church disputes; modern adjudications routinely look to extrinsic evidence to give vague terms the ineaning necessary to decide a conflict. ${ }^{125}$ The same principles used to discern the intentions of the parties or the existence of an agreement-trade usage and course of dealing-are particularly potent sources of information for curing vagueness in contracts. They are relevant sources in the context of church disputes as well.

Nevertheless, there will be an occasional case in which the court cannot resolve critical ambiguities in the agreeinent. In order to "function" within the meaning of the Tikhon ukase, does the hierarchy have to be entirely free froin influence by the Soviet government? The answer unay be clear when all of the circuinstances surrounding issuance of the ukase are considered, but what if it is not? There is nothing about this problem unique to church disputes. In a well-known cominercial case the buyer insisted that he was entitled to a shipment of broiling or frying chickens, while the seller maintained that his shipment of stewing chickens satisfied the terms. ${ }^{126}$ The actual agreement merely specified "chickens," and the available extrinsic evidence, including customs of the trade, was not helpful. The buyer had brought the action, for breach of warranty, and he had the burden of proof. He therefore lost. But the buyer would have won on an action brought by the seller, for neither could the seller carry the burden of proving that his construction of "chicken" was correct. In effect, then, the court dealt with the case by leaving the parties as they were. Modern courts will strive mightily to avoid such an outcome, and in the commercial context it will be rare. It may more often be appropriate in church disputes. ${ }^{127}$ It is not a satisfying result, in church disputes or in chicken sales, but it is sometimes the only possible result. If it were necessary in the context of a church property dispute, then possession of the church

124. See text accompanying notes 107-12 supra.

125. See generally, Corbin, The Interpretation of Words and the Parol Evidence Rule, 50 CoRNELL L.Q. 161 (1965).

126. Frigaliment Importing Co. v. B.N.S. Int'1 Sales Corp., 190 F. Supp. 116 (S.D.N.Y. 1960). This case is discussed extensively in Corbin, supra note 125, at 164-70.

127. Internal church agreements may be ambiguous more often than commercial contracts, which are usually drawn up by attorneys or which rely on established forms with more certain meanings in the trade. In addition, courts in church disputes may find they have fewer external cues with which to resolve ambiguities. Judicial instincts about the parties' probable motivations and intentions can be fairly trustworthy in the commercial seuse, but they may be entirely off the mark in ascertaining the intentions of the parties to a church dispute. Thus, not only may the formal documents contain more ambiguities, but the court may be less well equipped to resolve those ambiguities they contain. Abstention may thus more often be appropriate. At soine point, a court will have so few clues as to the parties' probable intentious that any decision would necessarily affect the court's own preferences more than the parties', and in church disputes especially, that is a resnlt to avoid, since it contains the seeds of unconstitutional imtrusion. 
would remain with the party who held it going into court. The point is that in reaching this outcome the court would not be applying any special "church dispute" rule; it would be applying basic principles of contract law. No special amendment to our contract principle is necessary to deal with vagueness.

\section{Conclusion}

In most church disputes the issue is contractual in nature and can best be handled by ordinary contract principles. This approach is constitutionally the most defensible and is the surest method of inaintaining true governmental neutrality in private religious matters. The only supplemental principle required is one to guard against secular pronouncements of "true" doctrine, but cases requiring this principle will be rare.

III

\section{APPLYING EXTERNAL RULES}

Most church disputes involve claims that one party violated internal cliurch rules-churcl constitutions, bylaws, or property agreements. A few, however, involve claims that state-made rules have been breached. Development of a principle to govern application of all external rules to religious organizations is beyond this Article's ambitions. A comprehensive discussion would examine regulatory schemes such as the antidiscrimination laws, ${ }^{128}$ the National Labor Relations Act, ${ }^{129}$ and criminal proscription of marijuana smoking or polygamy when practiced as a part of religious doctrine. ${ }^{130}$ When the issue is narrowed to the use of external rules to decide internal churcl disputes, however, two issues emerge. They are the application of judge-made rules of procedural fairness in associational governance, and the use of charitable trust rules concerning the employment and inanagement of charitable assets. Both issues present the potential for courts to impose government-created policies on religious organizations-a violation of the religion clauses. Application of the contract.principle, lowever,

128. See Bagni, Discrimination in the Name of the Lord: A Critical Evaluation of Discrimination by Religious Organizations, 79 CoLuM. L. REv. 1514 (1979).

129. See, e.g., Catholic Bishop of Chicago v. NLRB, 559 F.2d 1112 (7th Cir. 1977), affd on statutory grounds, avoiding constitutional issues, 440 U.S. 490 (1979). See Comment, Are Churches Above the Law? The Application of the Fair Labor Standards and the Equal Pay Provision of Tille VII to Religious Organizations, 40 U. Pitt. L. Rev. 465 (1979).

130. See People v. Woody, 61 Cal. 2d 716, 394 P.2d 813, 40 Cal. Rptr. 69 (1964) (bar on use of peyote found unconstitutional as applied to members of Native American Clurch); Reynolds v. United States, 98 U.S. 145 (1878) (law barring polygamy constitutional as applied to Mormon Churcli). 
can resolve many of these cases while avoiding constitutional difficulties.

Courts deciding internal church disputes use two types of external rules: gap-filling rules and policy-based rules. A gap-filling rule, although external in the sense that it is formally generated by judges or legislators rather than by the parties, is intended to express the understanding that the parties probably would have liad, if only they had considered the point. Both corporate and contract law are full of gapfilling rules. In corporation codes sucl rules are usually fiagged by clauses that allow a different result if corporate articles or bylaws so provide-that is, if the parties have in fact expressed themselves on the point. ${ }^{131}$ Similarly, the Uniform Commercial Code is replete with provisions that apply in the absence of soine express agreenent on the matter by the parties. ${ }^{132}$ Gap-filling rules are, of course, based on a policy-the policy of sustaming the contract, even by filling gaps, if necessary. The ultimate goal of that policy, however, is to effect the substance of the parties' agreenent. Policy-based rules, on the other hand, have the purpose of furthering external values, to be imposed upon the parties regardless of their agreement. Whether generated by the courts or the legislature, they impose a policy favored by the government, such as that corporate directors be chosen by cunulative voting, ${ }^{133}$ or that interest rates not exceed eighteen percent.

The distinction between gap-filling rules and policy-based rules is critical in deciding whether externally generated rules can be applied to rehigious corporations. Only the application of pohicy-based rules creates true state interference, potentially raising difficult constitutional problems; when the state imposes its own values on a religious organization, religious freedom is threatened. The application of gap-filling rules, on the other hand, is often inerely the use of the contract principle in another guise. When a court apphes to warring parties a rule that the surrounding facts indicate they probably intended, or a rule that their explicit agreeinent seems logically to require, it is performing the saine function as when it applies internal rules or construes church contracts. In eacli case the court seeks the outcoine inost consistent with the parties' intentions and is not imposing its own values on a rehigious organization.

Under this analysis it becones critical to identify whether a particular rule is properly characterized as gap-filling or policy-based. In eacli context considered lere, the rules have both policy and gap-filling

131. For example, Model Bus. CoRP. ACT $\$ 35$ provides that the board shall manage the affairs of the corporation, except as the articles may otherwise provide.

132. E.g., U.C.C. § 2-207(3).

133. See, e.g., CAL. Corp. Code $\$ 708$ (West 1977). 
functions, and it is necessary to tease these apart in order to determine whether use of the rule to adjudicate a particular internal dispute poses constitutional difficulties.

\section{A. Procedural Fairness}

Procedural fairness is a broad concept, but it is the theme that unites nonprofit organization cases arismg in three different contexts. These are the conduct of meetings, the election of directors, and the expulsion of members. Most of these cases can be decided by gapfilling and therefore should present no constitutional problems when religious organizations are involved.

An example of a controversy over conduct of a meeting in a secular settimg is Hatch v. Emery. ${ }^{134}$ That case involved an osteopathic hospital that was organized as a nonprofit corporation. The corporation had seventy members: sixty osteopathic physicians, and ten lay members who also served as the board of directors and were thus the ultimate autliority in internal governance matters. A dispute arose between a substantial majority of the members and the board over a proposal by the physicians to amend the articles of incorporation. The physician members scheduled a special membership ineeting to consider their proposal. The directors responded by meeting a few hours before the membership meeting and, pursuant to the corporate bylaws, admitting 159 new members into the corporation. The new inembersfriends, relatives, and associates of the directors-immediately signed proxies in favor of the incumbent board, which then used the proxies to defeat the physician-sponsored amendment and enact their own amendment making the board self-perpetuating. Under that amendment there would be no more elections for director; instead, the board would fill its own vacancies. ${ }^{135}$

Management's actions violated neither state law nor the corporate articles or bylaws, but they were still overturned in court. The court spoke of the fiduciary obligations of management to membership and said that the hospital's management had violated "a duty of fair dealing."136 The court elaborated by saying that the. board's action was "particularly offensive to our sense of fair play."137 Most readers

134. 1 Ariz. App. 142, 400 P.2d 349 (1965).

135. Such an arrangement is ordinarily allowed under state corporation laws. See, e.g., Brown v. Memorial Nat'l Home Foundation, 162 Cal. App. 2d 513, 521, 329 P.2d 118, 122 (2d Dist. 1958), cert. denied, 358 U.S. 943 (1959). New York purports to require nonprofit corporations that are not charitable to have members, N.Y. Nor-FOR-Profir CoRP. LAw $\$$ 601(a) (McKinney Supp. 1980), but nothing in the statute would appear to prevent the corporation from designating the directors as the only members.

136. 1 Ariz. App. at 146,400 P.2d at 353.

137. Id. 
would share that reaction.

But what is "fair play"? Is the court imposing some external standard of fairness here? Probably not. As applied in Hatch, "fair play" ineans that the offenders liave not played by the rules. Their actions may have been consistent with the pieces of paper that recorded the official agreement, but they were not consistent with reasonable expectations of what the agreeinent ineant. The articles may have authorized the board to admit new inembers, but surely it was not intended that they could use that power to pack the nembership before an important vote. Such a construction would give the board an unreasonable aunount of power-unreasonable not as tested against external values, but as inconsistent with the denocratic structure that the parties had otherwise chosen. That inconsistency suggests that the board violated the internal understanding. It should take nore persuasive evidence than a boilerplate bylaw provision on new nembers to persuade us otherwise. ${ }^{138}$ The language einployed by the Hatch court is one of external rules; the court itself makes no effort to find support for its ruling in the parties' agreeinent. But despite the court's appeal to external rules, it did not impose externally generated values. The court in Hatch was only closing an unintended loophole-filling a gap-consistent with the substance of the parties' understanding. ${ }^{139}$ Thus understood, the court's decision can be justified as an application of the contract principle.

The approach to fairness in Hatch will not necessarily produce results consistent with any one external value, because a court that insists that parties "play by the rules" will be looking at different sets of rules in different organizations. This is illustrated by an old California case called Erickson v. Gospel Foundation, ${ }^{140}$ which dealt with procedural fairness in the reinoval of a director. The decision does not indicate exactly what the Gospel Foundation did, although its corporate purpose was to proinote "evangelistic and mission enterprises."141 It had three members, who also served as the three directors. One of the three gave the foundation property worth over a million dollars. He died shortly thereafter, and the plaintiff was elected in his place, as the deceased benefactor had requested. Meanwhile, Miss Liddecoat, one of

138. See note 178 infra.

139. The Hatch court was not faithful to the literal terms of the expressed agreement, but that is lardly a cause for concern. A modern court is supposed to look beyond form, to substance. Since it is asked to decide the dispute, it ought to do so consistently with the parties' understanding, and it need not limit itself to a literal reading of the articles and bylaws in identifying that uuderstanding. There is nothing unusual about a court performing such a function, although it is not always described that way. See text accompanying notes 113-27 supra.

140. 43 Cal. 2d 581, 275 P.2d 474 (1954).

141. Id. at 583, 275 P.2d at 476. 
the two original board members, had taken advantage of a bylaw provision that allowed each member an extra vote for every $\$ 1,000$ contributed to and accepted by the foundation. She had contributed $\$ 2,000$, giving her three votes. When she was annoyed by plaintiff's suggestions that the corporation solicit funds for missionary work in South America, she called a mcmbership meeting to consider his expulsion. Her motion to expel was passed, three votes to one, with plaintiff abstaining. Under the corporate bylaws his loss of membership also terminated his position as a director.

The California Supreme Court sustained the expulsion, after concluding that it was in good faith and that the procedure followed came close enough to meeting due process requirements for an "organization such as the Foundation." 142 Thus described, the case seems like an outrage, or at least unfair. But the provision for termination was inserted, as the court saw the facts, because the corporation's founders "were of the opimion that harmony among the members was essential." 143 They wished therefore to provide for elimination of any discordant notes, through the technique of expulsion. And consistent with this approach, they in effect chose Miss Liddecoat as the arbiter, for it was the original board, mcluding the short-lived benefactor, which voted to accept her donation and thereby give her the additional votes that assured her control over the foundation. It was only after she caine to power that the plaintiff joined the team. In such a small, fainily-run affair, it seems certam that he knew the rules, but he still insisted on promoting causes that Miss Liddecoat opposed. His ouster was mevitable. It may not have been fair, but it was "fair play"; 144 the expulsion was consistent with the spirit as well as the letter of the organization's rules. There was no unintended loophole liere, no gap that needed filling.

Erickson and Hatch do not involve the application of a common primciple of governance imposed on the organizations before them, but rather reflect the application of a priniciple that looks to the association's internal arrangements as its guide. ${ }^{145}$ Other decisions, imvolving religious organizations, are consistent with this principle. The most

142. Id. at $587,275 \mathrm{P} .2 \mathrm{~d}$ at 478 .

143. Id.

144. A similar distinction is drawn by B. Barry, Justice and Fairness, in PHILOsOpHY of LAw 271-75 (J. Feinberg \& H. Gross eds. 1975). Barry uses the terms "background fairness" and "procedural fairness."

145. Erickson is sometimes thought to illustrate judicial reluctance to becoine involved in reviewing expulsions in religious societies, although the court itself does not so hold. Indeed, the court assumes, without deciding, that the procedural regularity of expulsious may be reviewed. 43 Cal. 2d at 586, 275 P.2d at 477; accord, Abysinnia Missionary Baptist Church v. Nixon, 340 So. 2d 746 (Ala. 1977); Baugh v. Thoinas, 56 N.J. 203, 265 A.2d 675 (1970). 
common cases involve the expulsion of one faction of the church by the other, voted on at a purportedly proper ineeting of the congregation. These are churches in which the power to expel undeniably belongs to the congregation's inajority, and church rules governing the conduct of such meetings may be sparse, or nonexistent. The expulsions typically take place with no notice or hearing, since they result from pohtical opposition rather than some individual offense, ${ }^{146}$ and the courts latch onto these "due process" failings to justify their intervention. In the absence of specific internal authority on the point, the court will extrapolate frond the church's concededly democratic polity to find that the expulsion is not authorized. ${ }^{147}$ The court fills the gaps in a way consistent with the general understanding.

In one colorful case, the pastor had been exposed as an adulterer, and responded to criticism of his behavior with threats of violence. When his opponents sought to organize a proper church meeting at which his termination would be considered, he called his own rump meetimg first, at which his opponents were all expelled. The court overturned the expulsions, observing that a meeting called without notice of its time, place, or purpose was inconsistent with the polity of the church $^{148}$ and with the internal understanding of its governance principles. ${ }^{149}$

There are analogous cases involving disputes over elections and the conduct of church meetings, although they seem less common. ${ }^{150}$

146. See, e.g., Epperson v. Myers, 58 So. 2d 150 (Fla. 1952); Randolph v. First Baptist Church, 53 Ohio App. 288, 120 N.E.2d 485 (1954).

147. Randolph v. First Baptist Church, 53 Ohio Op. 288, 296-97, 120 N.E.2d 485, 489 (1954).

In overturning such an expulsiou, the court may rely on the testimony of religious authorities that notice and hearing are required under church rules. See, e.g., First Baptist Church of San Marcos, Colored v. Giles, 219 S.W.2d 498, 501 (Tex. Civ. App. 1949).

148. David v. Carter, 222 S.W.2d 900 (Tex. Civ. App. 1949).

149. Several cases liave sustained such expulsions. Bear v. Reformed Meımonite Church, 462 Pa. 330, 341 A.2d 105 (1975); Mangum v. Swearingen, 565 S.W.2d 957 (Tex. Civ. App. 1978). In Sapp v. Callaway, $208 \mathrm{Ga} .805,69$ S.E.2d 734 (1952), the trial court concluded that the validity of the challenged expulsious turned on whether plaintiffs were correct in asserting that church doctrime barred membership in labor unions, and therefore instructed the jury to decide that question. In a foreshadow of Hull, the decision was reversed as an improper civil court determination of religious doctrine.

150. Conduct of meetings: In re Galilee Baptist Church, 279 Ala. 393, 186 So. 2d 102 (1966); Berger v. Amana Soc'y, 253 Iowa 378, 111 N.W.2d 753 (1961); Nelson v. Ellis, 140 So. 2d 194 (La. App. 1962); Hopewell Baptist Church v. Gary, 111 N.J. Super. 1, 266 A.2d 593 (App. Div.), affd, 57 N.J. 166, 270 A.2d 909 (1970).

Cases on election of directors seem especially unusual. In Burnett v. Banks, 130 Cal. App. 2d 631, 279 P.2d 579 (1st Dist. 1955), the court supervised an election of directors after concluding that church bylaws required an election but that the two church factions were so bitterly divided that neither could conduct a fair election. Contra, Williams v. Jones, 258 Ala. 59, 61 So. 2d 101 (1952). There are many cases involving the fairness of election procedures in secular nonprofit corporations, almost all of which involve the affiliates of the American Automobile Association. E.g., Braude v. Havemer, 78 Cal. App. 3d 178, 144 Cal. Rptr. 169 (2d Dist. 1978); Braude v. 
In Randolph v. Mt. Zion Baptist Church, ${ }^{151}$ the congregation was sharply divided over the question of whether to sell their old church building and hold services exclusively in a new building they had recently acquired. The faction favoring sale of the old building included the board of trustees and the pastor and was thus able to control the conduct of church meetings. They issued a meetimg notice that included hittle detail on the offer to purchase the old building. At the meeting itself they allowed no discussion before the vote. Just before the vote was actually taken, the pro-sale group suddenly brought into the meeting the entire junior choir, 50 to 100 strong, consisting of the children of those members who attended services at the new building. The children voted unanimously in favor of the sale, which was approved by a margin of 152 to 92 . However, that approval was upset im court.

All of the circunistances surrounding the vote combimed to influence the court, but the pro-sale faction's stratagem with the choir seemed particularly important. Church rules were unclear on whether children could vote. Baptist tradition apparently permits it, although individual Baptist churches vary in their practice, and the issue had not arisen in this church. There was thus no firmly established rule. Nor was there an established practice. It appeared that children had probably voted at times im the past, although no issue was made of it. But to the court, the use of their vote here seemed unfair. The pastor had called the choir to a special rehearsal that might, so that they would be on hand to vote, but none of those who sang at the old church, the children of the anti-sale faction, were called to the rehearsal. The court observed that if the anti-sale group "had anticipated the unusual maneuver they might have brought their own children en masse, but they were taken by surprise. A distorted vote resulted."152

The court's decision is justified as an exercise in gap-filling. If the case had presented only the question of whether children could vote, a decision would have been difficult since the facts were ambiguous. But resolution of that issue was rendered unnecessary by the overall strategy adopted by the pastor and his supporters. Where the propriety of a youth vote remained in doubt, the parties tolerated the occasional, randoin participation of children in the "chorus of yeas and nays"153

Havenner, 38 Cal. App. 3d 526, 113 Cal. Rptr. 386 (Ist Dist. 1974); Dozier v. Automobile Club, 69 Mich. App. 114, 244 N.W.2d 376 (1976); Valle v. North Jersey Auto. Club, 125 N.J. Super. 302, 310 A.2d 518 (1973).

151. 139 N.J. Eq. 605,53 A.2d 206 (1947).

152. Id. at $608-09,53 \mathrm{~A} .2 \mathrm{~d}$ at 209.

153. Id. Children's voting is apparently a recurring ambiguity in Baptist churches. See Hopewell Baptist Church v. Gary, 111 N.J. Super. 1, 266 A.2d 593 (App. Div.), affd, 57 N.J. 166, 270 A.2d 909 (1970). 
which concluded the resolution of noncontroversial items. That was the traditional practice. Yet while children who happened to be present might participate, they would not be specially invited, urged to attend, or instructed how to vote-certainly not secretly by those in charge of the ineeting. The pastor and trustees conducted their campaign secretly to avoid alerting the other side that they intended to play by new rules that would permit the marshaling of the youth vote. The result in Mt. Zion is thus reminiscent of Phoenix Hospital; it employs the same principle.

The principle is gap-filling-it is the apphication of rules that are called for by the overall agreeinent within the organization. Statutory or judge-made rules imposing externally generated governance norms on a church create constitutional difficulties, but such cases should not be confused with those surveyed here. Cases like Mt. Zion and Hatch employ a principle based on the parties' agreement and not on externally generated values, and that principle can be applied in church cases with no constitutional difficulty. It is a religiously neutral basis for adjudication, and, as an adjudication which follows the parties' agreement, it is a better choice than refusing to adjudicate at all.

\section{B. Fiduciary Obligations}

Section A showed that in enforcing rules of procedural fairness, courts are in fact often vindicating internally generated values. This section will show that the same is often true when courts apply traditional trust law principles to the nnanagement activities of church leaders.

A careful examination of traditional trust law and the fact situations to which it applies reveals that it is often used to vindicate interests of donors that are really contractual in nature. When so used, trust principles function as gap-fillers, and their apphication to churches can be justified by the contract principle. The law of trusts, however, also includes a body of well-established, externally generated rules that do not always make internal understandings relevant to the outcome. These are policy-based rules, and since they generate intervention considerably in excess of anything that the contract principle would sustam, they create constitutional difficulties. Separating the gap-filling cases, supported by the contract principle, from the remaming cases, is the principal purpose of this section.

\section{The Traditional Trust Rules}

Putting aside the fine print, charitable trust law contains three basic principles to guard against mismanageinent of an organization's funds. First, assets nnust be used for the trust purpose; so that, for ex- 
ample, a charity whose assets are dedicated to relief of lepers cannot suddenly abandon tliat program and commence running an art museum. ${ }^{154}$ Second, and a logical corollary of the first principle, any noncliaritable use of the assets is barred; charitable assets must not be diverted to private gain. ${ }^{155}$ This principle bars more than theft. Trustees are also supposed to refrain from "self-dealing" transactions-that is, transactions they negotiate on belialf of the trust but in whicl they have some personal financial interest. ${ }^{156}$ This is a prophylactic rule designed to avoid the temptation inherent in that situation to deal unfairly with the charity. ${ }^{157}$ The third principle is concerned witl care. The trustees of a charity, like the directors of a private business corporation, can be lield liable for losses that the organization sustains as a result of their negligence in carrying out their duties. ${ }^{158}$ As will be explamed below, in large part these rules are consistent with the contract principle in that they seek to lonor the donors intentions. ${ }^{159}$

154. Such a rule can be interpreted very strictly, as where a charitable institution whose articles included among its purpose the operation of "a hospital in the city of Los Angeles . . . to furnish . . . hospital care" was found to have improperly abandoned its trust purpose when it closed the hospital and apphed its assets to the inaintenance of an outpatient clinic. Queen of Angels Hospital v. Younger, 66 Cal. App. 3d 359, 136 Cal. Rptr. 36 (2d Dist. 1977).

155. E.g., People v. Larkin, 413 F. Supp. 978 (N.D. Cal. 1976).

156. E.g., id.

157. Although state laws differ in the details of their application of the prohibition agamst self-dealing to charitable corporations, there is ordinarily soine inechanisin by which otherwise improper transactions may be ratified or approved. People v. Larkin may be thought of as exemplifying the "strict" rule, consistent with the case law on private trusts. See also In re Anneke's Trust, 229 Minn. 60, 38 N.W.2d 177 (1949). Where the danger of repeated abuse exists, a court may dissolve a charitable corporation and order its assets transferrcd to some other similar charitable entity that would more reliably further the trust purpose. See, e.g., Eurich v. Korean Foundations, Inc., 31 Ill. App. 2d 474, 176 N.E.2d 692 (1961). But other cases have permitted the directors of a corporate charity to retain their profit froin a self-dealing transaction if they have demonstrated that the transaction was fair to the charity. See, e.g., Kelmey Presbyterian Hoine v. State, 174 Wash. 19, 24 P.2d 403 (1933). See the discussion in M. Fremont-Smith, FoundATIONS AND GOVERNMENT 137 (1965). In its recent codification of nonprofit law, California abandoned the absolute bar on self-dealing transactions by charitable directors, but it does place a heavy burden on thein in defending a challenged transaction. CAL. CORP. CODE $\$ 5233$ (West Supp. 1980). One celebrated case, Stern v. Lucy Webb Hayes Nat'l Training School for Deaconesses and Missionaries, 381 F. Supp. 1003 (D.D.C. 1974), applied the "less stringent corporate rule" to charitable directors with no inore analysis than the imild observation that this seemed to be the trend. It is difficult to demonstrate such a trend in the cases on charitable trusts, however, or in trust law generally.

158. See, e.g., CaL. Civ. Code $\S 2259$ (West 1954); CaL. Corp. Code $\$ 5231$ (West Supp 1981); Lynch v. Redfield Foundation, 9 Cal. App. 3d 293, 88 Cal. Rptr. 86 (2d Dist. 1970).

159. There is another aspect of trust law that inay prove unconstitutional when apphed to religious organizations. A state's attorney general, who has the power to enforce trust standards, may participate on behalf of one church faction, lending the resources of the government to one side and creating improper government intrusion.

In most states, the attorney general, not a charitable trust's beneficiaries, enforces compliance with trust standards. See, e.g., People v. Christ's Church of the Golden Rule, 79 Cal. App. 2d 858, 181 P.2d 49 (2d Dist. 1947); Karst, The Efficiency of the Charitable Dollar: An Unfulfilled State Responsibility, 73 HARv. L. REv. 433, 451 (1960). Since there is no identified beneficiary of a 


\title{
2. The Use of Trust Principles to Vindicate Donors' Contractual Interests
}

\author{
Allegations by church members that trust principles have been vi- \\ olated ${ }^{160}$ are usually accompanied by other contentions-for example,
}

charitable trust, no particular individual will necessarily benefit from its enforcement. Potential beneficiaries therefore usually have no standing to sue. In many statcs, however, there are private individuals with standing to enforce trust rules. They include directors of the charitable corporation, e.g. , Holt v. College of Osteopathic Physicians and Surgeons, 61 Cal. 2d 750, 394 P.2d 932, 40 Cal. Rptr. 244 (1964); members of the corporation, e.g., Wickes v. Belgian Am. Educ. Foundation, Inc., 266 F. Supp. 38 (S.D.N.Y. 1967); N.Y. NoT-FOR-PROFIT CoRP. LAW 623 (McKinney Supp. 1980); and contributors and sometimes even beneficiaries, e.g., Stcrn v. Lucy Webb Hayes Nat'1 Training School for Deaconesses and Missionaries, 367 F. Supp. 536 (D.D.C. 1973). These private groups may gain standing upon being granted "relator" status by the attorney general. See Wiegland v. The Barnes Foundation, 374 Pa. 149, 155-57, 97 A.2d 81, 83-84 (1953).

When a private party alone sues to enforce trust laws, it may be possible to avoid constitutional difficulty. When the attorney general prosecutes, however, the problem may be more complex. Prosecutions are often done in tanden with those having standing or in response to the complaints of those close to the organization who are in a position to know of the problem. In these situations, the attorney general is really intervening in an internal dispute between the "management" and a dissident faction that claims that manageinent is failing to meet its obligations. See People v. Worldwide Church of God, Inc., No. C-267-607 (Los Angeles County Super. Ct., filed Jan. 2, 1979); Press Release issued by California Attorney General, Oct. 14, 1980. Whether the private parties appear in the caption or the attorney geueral is rcsponding to a complaint, his participation on behalf of one faction may be unconstitutional governinent imtrusion, regardless of whether the courts employ religiously neutral rules in deciding the dispute. Pcrhaps these issues should be raised only in private actions brought by donors or church members. But if suits by the attorney general are barred, jurisdictions that might otherwise deny standing to private individuals would need to reconsider that position, lest no party with standing remain. Resolution of this subsidiary question is not aided by the contract principle, however, and will not be addressed here.

160. Disputes in congregational churches often involve allegations of financial misınanagement. See, e.g., Board of Incorporators of African Methodist Episcopal Church v. Gaston, 343 F. Supp. 823 (N.D. Ala. 1972); Providence Baptist Church v. Superior Court, 40 Cal. 2d 55, 251 P.2d 10 (1952); Miller v. McClung, 4 Mich. App. 714, 145 N.W.2d 473 (1966).

Although the number of reported decisions is not large, serious allegatious of financial misinanagement in churches arise with some frequency. See, e.g., People v. Worldwide Church of God, Inc., No. C-267-607 (Los Angeles County Super. Ct., filed January 2, 1979). The coinplaint in Worldwide Church alleged that the defendants, church leader Herbert Arnistrong and church financial officer Stanley Rader, were liquidating church properties on a massive scale, at prices below market value, so as to put thein "into a form in which they may be more easily appropriated to the personal use and benefit of the individual defendants." Id. (Complaint at 7-8). Involved were assets in excess of $\$ 80$ million. Id. This case received considerable national attention. E.g., Wiley, A Constitutional Outrage, LiberTy, May-June 1979, at 2; New York Times, Feb. 4, 1979, $\$ 1$ at $15, \mathrm{col}$. 1 . The only recent clurch-related scandal involving allegations of comparable magnitude was the prosecution of the Very Reverend Guido John Carcich, the fund-raising director of the Pallotine Fathers of Baltimore, a Roman Catholic nissionary order. He ultimately pleadcd guilty to charges of diverting $\$ 2.2$ million of charitable contributions into 28 secret bank accounts. C. BaKal, CharitY U.S.A. 103-04 (1979); Weeding Out Clergymen Who Go Astray, U.S. News \& WORLD REPORT, Oct. 2, 1978, at 63.

Many cases reach the newspapers but not the case reporters. Those recently noticed by the author include The Arizona Republic, Dec. 9, 1979, at 1, col. 3 (financial manager of the Tucson Roman Catholic Diocese under federal investigation for stealing church funds unsuccessfully sought to involve bishop in cover-up); N.Y.L.J., Jan. 30, 1980, at 1, col. 2 (treasurer of the New 
that internal decisionmaking procedures were not correctly followed. Indeed, these procedural claims are litigated more frequently than the substantive disputes. ${ }^{161}$ Claims of financial mismanagement can often be decided by resort to an analysis of church rules (as explained in Part II), or when those rules do not suffice, by a procedural fairness analysis (Part III, Section A). These approaches will not always suffice lowever, and an appeal to trust rules becomes necessary, changing the nature of the problem and requiring an analysis of the function served by those rules. ${ }^{162}$

York Annual Conference of the United Methodists Church improperly loaned out almost $\$ 5.8$ million to companies in which he was financially interested); Koten, Some Church Bonds Plunge Into Default; Investor Losses Mount, The Wall St. J., Feb. 27, 1980, at 1, col. 1 (survey of difficulties associated with various church bonds, many of which go bad because of the incompetence and sometimes the dishonesty of the pastor). The U.S. News \& World Report recently noted that the Philanthropic Advisory Service of the Better Business Bureau once got only a few letters a year concerned with religious fundraisers, but now finds that half of the 150,000 inquiries it receives yearly involve cluurch-related cliarities. Weeding Out Clergymen Who Go Astray, U.S. NEws \& WORLD REPORT, Oct. 2, 1978, at 63.

Incidents like these should not be surprising. The amount of inoney contributed annually to religious organizations is truly stupendous, and it is almost inevitable that some of it would fall into unscrupulous lands. Although no hard data on such contributions are available, estimates lave been prepared by the American Association of Fund Raising Counsel (AAFRC) based on samplings of statistics provided by major Protestant denominations, as well as extrapolations of sparse data available on Catholic and Jewish giving. For 1978, the AAFRC estimated that the total coutributions amounted to $\$ 18.4$ billion, or $47 \%$ of the total of all charitable contributions that year. C. BAKAL, supra, at 85. Filer Commission estimates for 1972 seem consistent with these figures. Commission on Private Philanthropy and Public Needs, Giving in America 57 58 (1975).

161. E.g., Board of Incorporators, African Methodist Episcopal Church v. Gaston, 343 F. Supp. 823 (1972); Konkel v. Metropolitan Baptist Churcl, 117 Ariz. 271, 572 P.2d 99 (App., 1977); Providence Baptist Church v. Superior Court, 40 Cal. 2d 55, 251 P.2d 10 (1952).

162. It is sometimes argued that the favored tax treatment allowed charitable organizations, including churches, justifies state supervision over their use of funds. In a limited sense this view is correct; certainly the public has an interest in whether or not it ought to subsidize any particular organization. The problem is that this interest has very little relationship to any trust law claim on behalf of donors or church members. The fact is that the tax code and the law of charitable trusts reflect different policy considerations, and need not be congruent. The tax law is concerned with which activities merit public subsidy; the charitable trust law is concerned with eusuring the integrity with which charitable assets are inanaged, in large part to protect the expectations of contributors. If one concludes that a tax subsidy is not justified, the obvious remedy is to terminate it. Such termmation of tax exempt status is adequate to satisfy the public interest in subsidization decisions.

Actual enforcement of traditional trust rules raises additional questions, and such an intrusion into internal church affairs requires additional arguments to sustain it. One could attempt to create a theory under which acceptance of tax-exempt status evidences consent to state charitable trust requirements, but such legal fictions are far froin satisfying. The reality is that such cousent is not normally present. What such a rule would really do is impose trust standards upon taxexempt churches as a matter of policy, whether they wish it or not. At a maximum this argument justifies offering a cliurch the choice of comphance and tax exemption, or noncomplance and no tax exeinptiou.

Eligibility to receive tax-deductible contributions is in fact largely conditioned upon compliance with traditional trust standards. Although it is rare for the Service to challenge the exemp- 
For example, in Greater Pleasant Green Baptist Church v. Robertson, ${ }^{163}$ the court considered a mortgage on the church property executed by the defendant, president of the church board of trustees, to obtain funds for his personal use. Such an act is an obvious, straightforward violation of fiduciary principles, and the court in fact ordered Robertson to make the church whole. Yet it did this without explicit rehance on any trust principles, restimg instead on the proposition that the mortgage was "unauthorized," there being no record of any meeting at which authority for the mortgage was given. ${ }^{164}$

If the court meant to suggest that authority of the membership was required before a mortgage could be given, that consequence flowed from the church's choice of governance structure rather than from externally generated fiduciary principles; for this point the court may simply apply church rules. Yet this rationale for the decision is troublesome, for it seems to suggest that the result would be different if, for example, a Roman Catholic archbishop were to place a mortgage on a piece of churcli property to raise funds for his personal use. He might well have the raw legal power to do so-lie might be the titleholder, as a corporation sole-but presumably suclı "autlorization" should not leave the cliurch remediless.

Whether a church is democratically or hierarchically governed, the mortgaging of the church property for personal benefit would involve a breach of duty by the church officer. That duty is owed to the church under traditional trust principles, which proscribe self-dealing by a

tion of a religious organization on the grounds that it is not a religion, see note 182 infra, it has denied tax-exempt status to purported religions whose financial arrangements indicate that they are organized for the personal gain of the founders, thus failing to comply with traditional charitable trust notions which bar the diversion of charitable assets to private gain. Bubbling Well Chureh of Universal Love, Inc. v. Commissioner, [1980 Transfer Binder] TAX CT. REP. (CCH) No. 39. This issue has been the basis of a running battle between the Service and the Church of Scientology. The Service won the opening round, Founding Church of Scientology v. United States, 412 F.2d 1197 (Ct. Cl. 1969), but subsequent forays lave been less decisive, see United States v. Cliurch of Scientology, 520 F.2d 818 (9th Cir. 1975); Churcli of Scientology v. United States, 485 F.2d 313 (9th Cir. 1973); Church of Scientology v. United States, [1975] 2 U.S. TAX. CAS. I 9651 (D. Hawaii). The Cliurch has counterattacked with law suits of its own. See The National L.J., July 9, 1979, at 1.

Nor is enforceinent of charitable trust principles conditioned on favored tax treatment in the case of secular organizations. The Sierra Club engages in too nuch pohitical activity to be exempt, but its contributors are still protected by cliaritable trust principles which require that their donations are spent to further the cause of couservation, not the mass production of large-bore hunting rifles, or the reinodeling of the Director's home. See Note, Income Taxes-Deductions: In General-I.R.S. Proposes to Revoke Sierra Club's Eligibility to Receive Deductible Contributions Because of the Club's Political Activities, 80 HARv. L. REv. 1793 (1967).

The tax laws and the charitable trust laws often deal with the same organizations, and the rules they einploy are similar, but the two laws are still different. We unust cxamine the policies associated with the trust law to determine whether it ought to apply to rehgious societies.

163. 343 So. $2 d 239$ (La. App. 1977).

164. Id. at 240 . 
trustee. It seems clear im both Robertson and the hypothetical that whatever authority had been granted the church officer to deal with church property, this personal use of that authority was not intended. If there was no exphicit agreement on that exact point, the trust principles operate to fill the gap, and their application here creates no constitutional problem. They simply vindicate an interest generated by private arrangement.

But what if there was no gap to fill? What if there was an agreement and it purported to authorize the improper mortgage? Should that change the outcome? The answer might initially seem "yes," if only a contract analysis is apphed. Using the approach developed in Part II, we would look to the governance structure adopted by the church to determine whether the agreement was authorized. In a Baptist church such as that involved in Robertson, church rules may put ultimate governing authority in the inembership, and their authorization would be adequate to satisfy all internally generated requirements. In the Roman Catholic Church the power would be with the hierarchy-indeed, there might be no other authorization needed. In either case, under church rules there might be an explicit agreement authorizing personal use of church funds by a church officer.

Even if the mortgage was authorized under church rules, our analysis might not be complete, for there could be a third party involved whose authorization might also be required under a contract principle: the donors. Of course, as a group they might largely overlap with the church members, but that might not always be the case. And in any event, in some hierarchical churches, the inembers, as nembers, would have no role. For example, the parishioners of a Catholic congregation have no governance authority. But their interests as donors can and should be analyzed separately. It is these donor interests, contractual in nature, which trust rules often protect. Thus, even if the mortgage was authorized under church rules, trust rules might prohibit it in order to protect the interests of the church's donors.

All three major trust principles can function to vindicate the donor's interest, expressing the unarticulated understanding that would norinally exist between donor and recipient organization. For example, under the first trust principle, a charity's assets must remain committed to the charitable purpose for which they were given. In some cases a donor may explicitly earmark a contribution, restricting its use more severely than the charity's charter might otherwise require. He may give funds to a university but specify that it inay only be used for a chair in a particular departinent. It is well established that such a re- 
striction is effective. ${ }^{165}$ In this case there is hardly a gap to fill. A court is rather honoring a restriction that the donor required and the university accepted; the restriction is the product of the parties' agreement. Trust rules do fill a gap, however, when the donor creates no special condition but gives an "unrestricted" gift to the university, for in that case the law also creates a restriction: the funds may not be used for any purpose beyond that to which the university's own charter dedicates its assets. ${ }^{166}$ That is a gap-filling rule, based upon a presumption that in choosing this recipient the donor intended that the funds go to further its charitable activities and not to some entirely unrelated program, such as rehef of the starving im Biafra or support of the local chamber of commerce. Indeed, the recipient's conduct, includimg the representations it makes im the course of its sohitations, can create trust obligations. ${ }^{167}$ Although no forinal trust document or declaration of trust exists, trust principles are employed im such a case to protect the donor's reasonable expectations as to how the funds will be used. ${ }^{168}$

Trust law thus presumes that the donor intended that his gift support the organization's established charitable purposes. But it also presumes consent to management of those assets by the orgamization's norinal governing structure. Absent an explicit agreement on the point between donor and cliurch, any donor consents to having the funds he contributes managed according to cliurch rules. If, for example, those rules placed great discretion in the church's hierarcliy, then the hierarcliy would have that discretion with regard to the particular contribu-

165. It has been said that, technically, a restricted gift to a charitable corporation does not create a trust. But in substance the result seems to be the same, since the attorney general will in fact enforce the restrictious, and the cy pres doctrine is available to modify thein im appropriate circumstances. The leading case on this point is St. Joseph's Hosp. v. Bennett, 281 N.Y. 115, 22 N.E.2d 305 (1939). The recent cases include In re Estate of Criswell, 20 Ariz. App. 157, 510 P.2d 1062 (1973); Mayor \& Alderinen v. West Annapolis Fire \& Improvement Co., 264 Md. 729, 288 A.2d 151 (1972); Lefkowitz v. Cornell Univ., 35 A.D.2d 166, 316 N.Y.S.2d 264 (1970), affd, 28 N.Y.2d 876, 271 N.E.2d 552, 322 N.Y.S.2d 717 (1971). See 4 A. ScotT, The LAW OF Trusts $\S 348.1$ (3d ed. 1967).

166. See text accoinpanying note 154 supra.

167. See Lefkowitz v. Coruell Univ., 35 A.D.2d at 172; 316 N.Y.S.2d at 271 . A charity may be required to spend its money on a purpose specified by the trust. In Commonwealth v. Barnes Foundation, $398 \mathrm{~Pa}$. 458, 159 A.2d 500 (1960), the court ordered the foundation to operate a public art inuseum, which the court read the trust instrument as requiring. The foundation had argued that it was fulfilling the trust by operating an art school.

168. Courts have on occasion explicitly recognized that trust rules perforn this function:

[A]ll the assets of a corporation organized solely for charitable purposes must be deemed to be inpressed with a cliaritable trust by virtue of the express declaration of the corporation's purposes, and notwithstanding the absence of any express declaration by those who contribute such assets as to the purpose for which the contributions are inade. In other words, the acceptance of such assets under these circumstances establishes a charitable trust for the declared corporate purposes as effectivcly as though the assets had been accepted froni a donor who lad expressly provided in the instrument evidencing the gift that it was to be held in trust solely for such charitable purposes.

Pacific Horne v. City of Los Angeles, 41 Cal. 2d 844, 852, 264 P.2d 539, 543 (1953). 
tion. This assumption is much like the assumption made by Justice Brandeis in the Gonzalez case concerning the disposition of the chaplaincy endowment at issue there. ${ }^{169}$ The presumption that the gift was intended to support the charity's established purposes and the presumption that the donor consented to manageinent of those assets according to the charity's rules might conflict if those rules were changed subsequent to the gift. Such a conflict is impossible, however, under traditional trust rules, which bar a charity's governing board from altering the trust restrictions applicable to existing assets. ${ }^{170}$

The other two charitable trust principles can be derived from the presumption that the gift was intended to support the charity's established purposes. If we presume that the donor intends for his gift to support a particular charitable endeavor, then surely we should also protect the gift from diversion to noncharitable use, or loss through careless manageinent, because these possibilities also defeat the same presumed intent. The rules, $\dot{m}$ effect, assume that a silent donor would have expressed these conditions if the question had been raised and that the charity would have accepted them.

An illustration of trust principles operating to protect such unexpressed donor interests is the case of Metropolitan Baptist Church, Inc. v. Younger. ${ }^{171}$ The church had been founded in 1952 and at one point had fifty inembers, but by 1970 it had come upon hard times, with ouly three members left besides the minister, his wife, and his son. These six remaining adherents inet and voted to dissolve the church. The question was how to dispose of its assets, totaling about $\$ 25,000$. The basic trust principle, that otherwise unrestricted charitable assets remam dedicated to the causes embraccd by that particular charity, applies upon dissolution, and the court supervising such a dissolution is supposed to ensure that the dead charity's "Iieirs" have purposes that resemble as closely as possible those of the decedent.

The problem is to estabhish what those purposes are. Following the same practice as is used with secular charities, ${ }^{172}$ the court ex-

169. See text accoinpanying notes 33-38 supra.

170. Traditional trust rules thus elevate the presuinption concerning the charitable purpose, although it is unclear that there is any basis for that choice, especially given the potential difficulty in establishing just what the charitable purpose of an organization is. Cases like Queen of Angels, discussed in note 154 supra, illustrate the potential for a very narrow reading. Indeed, organizations that did not even realize they were charitable sometimes discover that a court reads their purposes in such a way as to categorize thein so. Lynch v. Spilman, 67 Cal. 2d 251, 431 P.2d 636, 62 Cal. Rptr. 12 (1967); In re Los Angeles County Pioneer Soc'y, 40 Cal. 2d 852, 257 P.2d 1, cert. denied, 346 U.S. 888 (1953).

171. 48 Cal. App. 3d 850, 121 Cal. Rptr. 899 (1st Dist. 1975).

172. See, e.g., Holt v. College of Osteopathic Physicians, 61 Cal. 2d 750, 394 P.2d 932, 40 Cal. Rptr. 244 (1964); In re Los Angeles County Pioneer Soc'y, 40 Cal. 2d 852, 257 P.2d 1, cert. denied, 346 U.S. 888 (1953). Establishing whether a particular expenditure is within an organization's 
amined the corporate charter and church history and concluded that the charitable purpose was to operate a fundamentalist Baptist church in Richmond, California, where none had theretofore existed. The court then reviewed the distributees chosen by the six remaining church neinbers to determine whether they fit that purpose. The six had voted to distribute almost half of the assets to two fundamentalist Baptist churches in adjoming communities, a sixth to a servicemen's center in another part of the state, which was not "restricted to Baptist teachings," a twelfth to a local Baptist seminary, and a third to a fundamentalist Baptist church in a distant state, which had agreed to hire the departing minister.

Was this distribution in accord with the charitable purpose? The court found that in part it was not. It disallowed the grant to the seminary and the servicemen's center, since neither was a church and one was not even Baptist. The grant to the distant Baptist church had the color of self-dealing, since the departing minister and his family stood to benefit from it. The court chose to ignore this issue, however, disallowing the grant instead on the equally plausible ground that the church was too distant to serve the purpose of providing fundamentalist Baptist services to Richmond. Thus, the two nearby Baptist churches received the entire legacy, not only five-twelfths of it.

The court's inquiry contained the potential for forbidden doctrinal pronouncement, although discovernig what was meant by "fundamentahist Baptist" need not create that difficulty any more than finding the intended meaning of "Orthodox Judaism." 173 In any event, there was apparently no disagreement here which turned on that definition, with all parties conceding that the dissolving church, and the three potential church distributees, fell into this category. In this context it is easy to be comfortable with the result in Metropolitan. It does seem plausible that the church's donors were mitially motivated to give so that a fundainentahist Baptist church could be estabhshed in their community. When that goal became impossible, transferring the funds to the two closest churches, in faith and geography, was the nearest that the court could come to honoring that initial understanding. This is proper gapfilling.

Metropolitan illustrates how charitable trust rules can be employed by courts to vindicate the contractual interests of donors who may be

charitable purpose can be difficult, and courts have sometimes taken very narrow views of an organization's purposes. See note 154 supra.

173. That is to say, the issue here was the intent of the relevant parties-the donors and founders- just as that was the issue in the express trust cases discussed above, involving Orthodox Judaism. There is no need for the court to make a theological determination of "true" Baptist fundamentalism. See text accompanying notes 107-12 supra. 
otherwise unrepresented in organizational decisionmaking. This same approach might solve our problem with the Catholic bishop who mortgaged church property for his own use, since we might safely argue that trust law is merely honoring the unexpressed intentions that the various donors must have had when their funds were contributed to purchase the building in question. Yet it is also possible to imagine variations of this hypothetical that would not fit our gap-filling analysis nearly so easily. In fact, while examples we have considered thus far seem consistent with the contract principle advanced in Part II, there are at least two potential problem areas in which traditional trust practices cannot be explamed by reference to contractual principles.

\section{The Use of Trust Principles to Impose External Policies \\ a. Overriding Donor Consent}

Charitable trust rules can be constitutionally applied to church disputes so long as the donor's intent is honored. Sometimes, however, the trust rules may conflict with the donor's intent. Suppose, for example, in the Robertson case discussed above, ${ }^{174}$ there was evidence that the use of church money for the chairman's private gain both met with donor approval and had been properly authorized by the members. For a court to bar this use of the funds anyway, on the basis of a trust principle against self-dealing, could be explained only as the imposition of some external policy. Sustaining its application to churches would thus be constitutionally suspect, because donors would not be free to support their religion as they chose.

Overriding donor consent is a significant problem because trust rules do not traditionally have the flexibility for relaxation upon donor agreement. ${ }^{175}$ As a general rule, the law will not free charitable trustees from hability for careless or self-dealing transactions, even if such transactions have been authorized by the donor. Traditionally the law provides no inechanism at all for excusing carelessness, and the only mechanism available to permit self-dealing transactions is approval by a court, or by the attorney general, as a representative of the public

174. See text accompanying notes 163-64 supra.

175. One can find vague statements in the authorities suggesting some room for donor relaxation of trust standards, as by placing provisions in the trust instrument, but such statements are always followed by assurances that there are "minimum standards" that cannot be waived under any circumstances. Committee on Charitable Trusts, Duties of Charitable Trustees and Directors, 2 Real Prop.: Prob. \& TR. J. 545, 555 (1967); Freinont-Smith, Duties and Powers of Charitable Fiduciaries: The Law of Trusts and the Correction of Abuses, 13 U.C.L.A. L. REv. 1041, 1046 (1966). Under the new California Nonprofit Corporation Law, the donor's views regarding the investinent of the donated assets, if expressed in the instrument under which the gift was made, may permit acts that would otherwise be considered violative of the trustees' fiduciary duties. CAL. CORP. CODE § 5240(c) (West Supp. 1980). 
interest in charitable assets. ${ }^{176}$ The traditional rules, then, developed largely in a secular context free from first ainendinent considerations, seem to advance a policy of fiduciary standards that the parties are not free to vary-which presuinably serve additional, external values in addition to protecting the parties' understanding.

There is soine evidence that these rules are becoming more flexible in permitting departures upon donor authorization, but the trend is modest. ${ }^{177}$ There are a variety of possible explanations for this resistance, apart from the existence of some external values. It inay be that the question has arisen so infrequently that it has not been seriously considered. Or perhaps there is doubt that a satisfactory method for determining whether the conduct had been consented to can be found, since there are often many different donors whose gifts are commingled, and only some of them would consent to departures froin the presumed standards. But it is also possible that the law is thought to reflect some policy considerations in addition to the donor's intentions, which make his authorization inadequate to justify such departure. In other words, it is possible that the rules are policy-based, as well as gapfilling. The literature on trust standards is not lielpful on this point and certainly offers no suggestions as to what external policy might underlie and justify the law's traditional inflexibility. Proving a negative, such as the absence of a policy, can never be done with complete satisfaction, but there is certainly no articulated policy of substance involved here. ${ }^{178}$

176. See, e.g., CAL. CoRP. CODE $§ 5233$ (d)(1) (West Supp. 1980). Such approval, of course, would be granted only where the charity can be shown to benefit from the proposed transaction even though it would technically be self-dealing.

177. The provisions cited in note 175 supra are recent changes in the California law, and their modest relaxation of traditional rules has not yet been widely copied. The fact is that although there is agreement on the general principles we have discussed so far, there is no consensus in the law of imcorporated charities as to the details of these rules on fiduciary obligations. The cases are often in confusion, and in conflict. See note 157 supra. This does not undennine our argument that these provisions are in large part gap-fillers. There nnay be a variety of ways in which to deal with a situation that the parties themselves failed to provide for expressly. Partieularly as the level of detail increases, the decisionmaker will necessarily have to proceed nore on his own preference and less on a rehiable guess of the parties' intentions, whieh will not even be nascent at the detailed level. But this process is justifiable as a gap-filler so long as the general principles advanced are consistent with nornal expectations, and so long as the parties are permitted to provide otherwise.

178. One potentially significant pohicy justifying inflexible rules is the desire to establish a category of organization which is clearly recognized as adhering to traditionally strict trust standards. The policy, then, would be to maintain the integrity of that category and its label; there would be no problem with conducting the same offending transactions under a different label. This would, in effect, be the organizational version of a "truth-im-packaging" policy. The author has a paper now in progress which explores this possibility nore fully.

It must also be noted that rules inay be justified as gap-fillers even though they do not expressly provide for alteration by the parties. For exaunple, under the Uniforn Commercial Code a seller always warrants that the goods will be as described and there is no provision for the seller to avoid this warranty. See U.C.C. \$ 2-313(1)(b). Yet, it hardly seems logically possible for buyer 
The absence of an important external policy makes it difficult to justify the law's inflexibility, but that difficulty becomes constitutional when we seek to apply these standards to cluurches. Forbidding cliurcl leadership to use contributed funds for a purpose authorized by the donors surely requires the presence of some important policy of overriding concern.

\section{b. The Problem of Fashioning Presumptions}

Much of the defense of trust principles as gap-fillers rests on their filling those gaps im a manner consistent with the donors' presumed

and seller to agree on a price for 100 pounds of chickens, yet intend to permit the seller to fulfill his obligation by shipping 20 pounds of bananas. The Code inakes no provision for agreements allowing such a result, but that is inerely because it is virtually certain that no matter how extensively a contract purports to limit the seller's warranties, the parties intended him to have that minimal obligation. See id. §2-312, Official Comment 4.

Legislatures and courts may be particularly willing to adopt such rules because the process by which the contract was entered is often unpersuasive as an expression of the parties' intent. The use of standard forms that one or both parties fail to scrutinize carefully is common, and a court may believe that its rule is in fact more likely to reflect the probable expectations of the parties as to how a particular problem would be handled than is any provision that the form contract might contain. Of course, to the extent that this is the basis of the rule, it ought to yield when there is good evidence that the parties in fact intended a different result in the particular transaction under consideration.

Some of our fiduciary principles may seem so likely a part of donor expectations as to require such conspicuous consent for their waiver. A recent case demonstrates that the possibility is not entirely fanciful. In Younger v. Faith Center, 2 No. 56574 (Cal. Ct. App., Aug. 29, 1980) (unpublished), the attorney general's allegations of financial improprieties were inet by claims that every pledge slip contained the following disclaimer:

This Faith Promise is an expression of religious worship to God and as such is a clear expression of the donor's freedom of religion expression protected by the First Amendment ....

Any moneys paid on this Faith Promise does [sic] not create a charitable Trust but is [sic] contribution to my Lord Clurist through His agency the church.

Dr. Gene Scott as the Pastor of Faith Center . . . is expressly authorized to determine designation of these funds.

Assuming we are persuaded that there is genuine consent, can the state impose its fiduciary standards nonetheless? It seems that we cannot avoid soune kind of balancing test im answering this question. The rules presumably further some external policy, and the importance of that policy would have to be balanced against the burden on free exercise created by applying it to the religious community. There must be policies that can constitutionally be imposed on cliurches. The state may surely bar human sacrifice, no matter how central to religious doctrine, even when conducted upon willing victims chosen from the faithful. The parties' agreement is surely inadequate to overcome the state policy against unurder, which does not require the victim's objection as an element of the crime. State policies of less apparent weight have prevailed. The Court long ago decided that the state may impose its bigany laws upon Mormon polygamists. Reynolds v. United States, 98 U.S. 145 (1878). That decision is subject to criticisin, see, e.g., L. TRIBE, supra note 12, at 853-54 (suggesting that its logic is undermined by the subsequent decision in Sherbert v. Verner, 374 U.S. 398 (1963)), but it still seems clear that the first amendment does not guarantee churches absolute immunity from policy based regulation. The extent of permissible regulation will therefore have to be determined by some kind of balancing test, a familiar if unsatisfying legal tool. The precise design of the scale can be left to another day, although others have already addressed that issue. See, e.g., notes 128-30 supra. 
intent. That foundation may be shaky. The problem is that some of the law's initial presumptions about parties' intentions, derived from a secular context, may not fit churches.

Consider, for exainple, the Divine Light Mission, headed by the twenty-year-old Indian rehgious leader Guru Maharaj Ji, which has acquired between thirty and fifty thousand American followers since its expansion to this country in $1971 .{ }^{179}$ While those followers sleep on straw pallets, practice celibacy and vegetarianism, and abstain from alcohol and other worldly pleasures, the leader pursues a different lifestyle. So far as can be told, approximately sixty percent of the group's three million dollar annual incorne goes to sustain him. He has luxury homes in Denver, Los Angeles, New York, and London, as well as a fleet of chauffeured Mercedes and Rolls Royces. Obviously no secular charity could survive the scrutiny of state authorities if it einployed its assets in this manner. But that is because inaintaining such a hifestyle for the executive director of a fund to support cancer research could not possibly be justified as advancing the organization's charitable goals. It would be an improper diversion of charitable assets froin research to private gain.

That may not be the case with the guru, however. It is coinmon for rehgious leaders to live regally, particularly where their followers view them as prophets, with some special relationship to God, rather than as inere administrators. Nor does the Pope hive in a cold water flat. If we apply a rule that the use of church funds to provide a life of luxury to the guru does not serve a rehigious purpose but providing such support to the Pope does, we will be constricting the definition of "religious purpose" in an inupermissible manner. ${ }^{180}$ Such a rule would necessarily assume either that the guru, unlike the Pope, does not have the rehigious iniportance his followers assert, or that it is improper for soine religions, but not others, to devote substantial resources to maintain their leaders in comfortable affluence. Either view establishes an official, government-approved, religious doctrine, and is precisely the kind of rule that Hull and the ban on doctrinal decisions correctly bar.

Since church disputes cannot be decided by reference to a stateauthorized religious practice, other guidelines are needed. The most sensible are the parties' intentions: if the faithful consent to the guru's use of the funds, there is no basis for state intervention. A court should

179. The facts related here concerning the Divine Light Mission are taken from C. BAKAL, CharitY, U.S.A. 117 (1979).

180. Indeed, almost any state-generated definition of religion produces constitutional difficulties. The problem has most recently been reviewed in Note, Toward a Constitutional Definition of Religion, 91 HARV. L. REv. 1056 (1978). The value of a contract approach is that it avoids, in most cases, the need to deal with this question. 
not presume, as it does in the secular context, that a lavish lifestyle for the leadership is contrary to donor expectations. What would be selfdealing or outside the scope of the charitable purpose in a research fund inay not be in a church, and even the burden created by requiring evidence of consent to overcome an unwarranted presumption may be inore than ought to be required. Any application of even these gapfilling rules to churches inust therefore proceed with great caution.

If protecting donors' reasonable expectations concerning the use of their inoney is the legitimate interest to be protected, then the solution may be in addressing that interest more directly than we do by the application of ordinary trust law rules. Rather than framing the inquiry along the lines of traditional doctrine-was this use within the scope of the charitable trust? or, did the leadership here engage in a self-dealing transaction? - a court could ask: Were church funds used in a way that was inconsistent with the reasonable expectations of a substantial number of contributors? Such an approach avoids beginning witl any presumption concerning donor intent.

The concern thus becomes inore one of misrepresentation than of imposition of state generated rules of conduct on religious fiduciaries. ${ }^{181}$ This approach, in principle, would involve implying a contract between the donor and church leadership from the facts surrounding the contribution and enforcing its terins. This would certainly be a gap-filling process - the gaps might be greater than those we ordinarily fill in contract law-but the parties' own understanding would still be our guide. This analysis recognizes that religious freedom requires allowing the faitliful to support an appropriate lifestyle for a religious leader they view as a divine prophet, but it should not disable the contributors from seeking redress when the leader solicits contributions for the Asian poor, yet actually spends the funds on a private tennis court for his son. In that case we can apply religiously neutral rules to protect the interests of the donor-followers, even though those rules may be substantially different from traditional trust principles.

In applying this analysis to, for example, the gurn, a court would

181. It is certainly possible to create unconstitutional rules even where one's concern is misrepresentation, as was demonstrated in Village of Schaumburg v. Citizens for a Better Environment, 444 U.S. 620 (1980). There the Court struck down a law that effectively barred door-to-door solicitations by charities that spent more than $25 \%$ of their funds on administrative expenses, imcludimg salaries and payments to fundraisers. While "conduit" charities, which give away money, could meet such a requirement, charities that regularly worked at their goal through the efforts of their own salaried employees could not easily meet such a requirement. Thus, while the Schaumburg ordimance was motivated by a desire to protect local residents from fraudulent solicitations for organizations that were not genume charities, its aim was too unfocused, preventing solicitation in entire catcgories of genume charity as well. The Court conceded that the goal was appropriate, and constitutional, if pursued in a less overbroad fashion. Id. at 637. 
have to make a factual inquiry into the circumstances surrounding the particular case. That inquiry would not focus on doctrinal matters, such as whether the guru's lavish lifestyle served a vahid rehgious purpose. Rather, those challenging the expenditure should have to show that in soliciting support an expectation was created as to the use of these funds and that that expectation was violated by the expenditures on the guru. It seems unlikely that such a showing could be inade. The guru's followers appear entirely aware of his lifestyle, and it is evident that it is their money and effort which sustains it. There are not two millennia's worth of evidence, as with the Pope, but it seems clear enough.

Looking to the donors' expectations leaves "rehgion" undefined; proper use of church funds is limited only by the faitliful's desires and the leader's representations. In some branches of the law this could be troublesome. When the Internal Revenue Code includes religion within the charitable purposes qualifying for tax-exeinpt status, it may be necessary to employ an external definition of religion so as to place some limit on the benefits thereby conferred. We inight otherwise find ourselves with self-declared religious leaders whose faith emerges only at tax time. ${ }^{182}$ Yet such external definitions are notoriously difficult to

182. Where the Service does attempt to define religion, it is not always successful. See Universal Life Clrurch, Inc. v. United States, 372 F. Supp. 770 (E.D. Cal. 1974). The Service did not appeal the decision in this case and subsequently granted the church a ruling recognizing its taxexempt status. Scliwar, Limiting Religious Tax Exemptions: When Should the Church Render Unto Caesar?, 29 U. FLA. L. Rev. 50, 62 n.81 (1976). The Justice Department is generally reluctant to litigate this question. Id. But tax authorities may be forced to confront the problem to avoid major revenue losses. The Church of Scientology lias been held not a religion by statc tax authorities rejecting their application for property tax exemption. Missouri Cluurcli of Scientology v. State Tax Comm'n, 560 S.W.2d 837 (Mo. 1977), appeal dismissed, 439 U.S. 905 (1978). Eightyeight percent of the residents of Hardenburgh, New York recently became ordamed ministers of the Universal Life Church (available to anyone in exchange for a sniall fee), turned their lromes into clurches, and applied for property tax exemptions. The town is now doing battle witl the State Board of Equalization and Assessment. See Town of Hardenburgh v. State, 52 N.Y.2d 536, - N.Y.S.2d - (1981); In re Dudley v. Kerwick, 52 N.Y.2d 542, - N.Y.S.2d - (1981); In re Sbea v. Kerwick, 52 N.Y.2d 557, - N.Y.S.2d - (1981). New York is not alone. A Ploenix ministcr of the Universal Life Cliurcl recently took out a full page ad under the lieadline "The Fastest Growing Clurcl in the World: Religious Freedom, Tax Relief, Draft Exemption.” The ad promised "complete information and minister credentials" for ten dollars. Ariz. St. U. Press, Feb. 7, 1980, at 12 .

Sometinies the Service finds a "church" nonexempt without concluding expressly that it is not a "religion." The ruling is instead based on a finding of "private murement," see note 162 supra, or on a finding that the "churcli" was not operated exclusively for "rcligious purposes" because it holds no services or meetings, and performs no ceremonies or sacraments, see, e.g. , Bubbling Wcll Clrurch of Universal Love, Inc. v. Commissioner, [1980 Transfer Binder] TAX CT. REP. (CCH) No. 39, and Walter H. Pusch, 1980 Tax Ct. Mem. Dec. (P-H) \ 80,004, in which the court concluded that the Church of the Tolerants, with no charter or bylaws, liad as its "inajor function to protest the exemption from tax of clrurches."

The entrepreneurial motivations of sucl "religious" leaders may sometimes overcome their caution; if their lome can becone tax-exempt by labeling it a clurcl, perliaps their crimes can 
frame or administer; ${ }^{183}$ one is always on the edge of constitutional catastrophe. ${ }^{184}$ It is far better to avoid such difficulties if possible. It is possible in designing a rule to satisfy the trust law's essential concern with protectimg donors' expectations. By looking to the donors' intentions and the solicitors' representations to mark our boundaries, we fulfill the core purpose of these rules without announcing any official definition of religion.

Protecting the reasonably induced expectations of the faithful who have contributed to the church ought to be possible without creating constitutional difficulties. Religious views should not be burdened by making them the one charitable innulse that falls outside the law's protection. But where the trust doctrine is employed to impose external values on the faithful and the church-to bar them, for example, from the willing support of their leader-then it may exceed both wisdom and the Constitution. This may not always be an easy line to draw, but

become law-exempt in the same way. Hakeem Abdul Rasheed was recently indicted for mail fraud by a federal grand jury for conducting a classic Ponzi schenne, but with the new twist of operating it in the guise of a "church"--the Church of Hakeem. The faithful paid over $\$ 20$ million to the "church" in one year, lured by the leader's promise of $400 \%$ "increases of God" within 70 to 90 days. See Hakeem Indicted for Fraud, Perjury, Oakland Tribune, May 30, 1979, at 1, col. 2. Even in this case, a court recently held that forner church inembers who were bringing a civil fraud action against Rasheed could not obtain the "church's" nembership list because requiring production of such a list would violate rights' of association. Church of Hakeem, Inc. v. Superior Court, 110 Cal. App. 3d 384, 168 Cal. Rptr. 13 (1980). The IRS has successfully levied assessments on a "church" whose activities allegedly included the purchase of 33 tons of marijuana valued at $\$ 3.3$ million. Zion Coptic Church, Inc. v. United States, 79-1 U.S.T.C. I 9325 (C.C.H.), 44 A.F.T.R. 2d 79-5022 (S.D. Fla. 1979).

183. Religion is not the only use traditionally included within the common law concept of "charitable uses" that is difficult to define. Even relatively straightforward terms, such as education or research, have created problems, and it is not snrprising that rehigion is even inore difficult to define. The Restatement of Trusts offers a number of specific examples of activities that qualify as "charitable," but then adds a catch-all provision specifying that a "trust for the promotion of purposes which are of a character sufficiently beneficial to the community to justify committing property to be devoted forever to their accomplishment, is charitable." RESTATEMENT (SECOND) OF TRUSTS, $\$ 374$ (1959). It has been observed that "judicial appraisal of community benefit is to some extent a function of time and place." E. CLARK, L. LUSKY, \& A. MURPhY, Gratuitous TRANSFers, Cases and Materials 625 (2d ed. 1977). In addition to the cases cited therem, consider the difficulty faced by the Internal Revenue Service, which follows the common law definition of charity, in determining whether or not an organization is charitable for the purpose of I.R.C. $\$ 501(c)(3)$. Distinguishing public interest, "charitable," law firms, fron private law firms has been one continuing problem, see B. HopkINs, THE LAw OF TAX EXEMPT ORGANIZATIONS, 86-89 (3d ed. 1979), as has the application of the traditional charitable category of "education" to some organizations concerned with more modern issues such as feminisin and homosexual rights, see, e.g., Big Mama Rag, Inc. v. United States, 494 F. Supp. 473 (D.D.C. 1979), rev'd, 631 F.2d 1030 (D.C. Cir. 1980); Rev. Rul. 78-305, 1978-2 C.B. 172.

184. Laurence Tribe has pointed out that a more expansive definition of religion may be required in reviewing Free Exercise claims than in reviewing Establishment Clause claims. L. TRIBE, supra note 12, at 826-33. See also Note, Toward a Constitutional Definition of Religion, 91 HARV. L. REv. 1056 (1978). 
it is the one that the Constitution requires. ${ }^{185}$

\section{Conclusion}

Part III has shown that the contract principle has application in the two inost common kinds of internal church disputes involving appeal to external rules: disputes involving allegations of procedural unfairness or breach of fiduciary obhigations. Both involve gap-filling and thus are constitutionally permissible. Other disputes, however, involve policy-based rules, which raise different and more difficult constitutional issues when apphied to rehgious organizations.

\section{CONCLUSION}

This Article began with the observation that there was a tension between organizational autonomy and other interests of the church and its members, a tension that colored the constitutional issues. The analysis advanced here is largely a response to that tension. It would be simple indeed to deal with all of these conflicts with a pohicy of nonmvolveinent-a rule that no matter what the complaint, it will not be heard in a secular court, a rule that the court would "refuse to be a judge of these things." But courts serve neither the church nor its members by placing their affairs im a special law-free zone. Law-free is also lawless, and the consequence is that neither the faithful, nor the church or those with which it deals, can rely on the other parties playing by the rules, for there are then no enforceable rules.

If providimg rules required imposing upon churches governmentally-inspired primciples of church governance, serious constitutional problems would be raised. But the interests of both church members and church organizations can largely be met without resort to that course. The solution most of the time is to honor internal church agreements, just as a court would honor the internal agreements of a secular organization. Only when doctrinal decisions or the imposition of external policies are involved need a court refrain from deciding a dispute. This approach serves both organizational autonomy and the other interests of the church and its members, while preserving the rehgious neutrahity demanded by the first amendment.

185. A balancing process will probably be required to determine whether any particular policy-based rule can constitutionally be imposed on religions, although the details of that process are beyond the scope of this Article. See note 178 supra. Clearly, however, soine rules may be allowed. For example, there seems to be no difficulty in requiring an incorporated church to coinply with routine filing formalities in order to amend their articles of mcorporation. Ragdall v. Church of Christ, 244 lowa 474, 55 N.W.2d 539 (1952). 